\title{
CAPM, INDEKS TUNGGAL DAN TREYNOR SEBAGAI ANALISIS PORTOFOLIO PADA SAHAM SYARIAH
}

\author{
ERY INDAH SETYOWATI * \\ HUSNURROSYIDAH * \\ Institut Agama Islam Negeri Kudus \\ *ery.indah20@gmail.com \\ **husnurrosyidah@iainkudus.ac.id
}

\begin{abstract}
This study aims to analyze the optimal portfolio of stocks using a single index model and the Capital Asset Pricing Model (CAPM) in making investment decisions as well as the expected profit and risk of the optimal portfolio formed on Islamic stocks in the Indonesian Sharia Stock Index (ISSI) on the Indonesia Stock Exchange. 2016-2020 period. This research design is descriptive quantitative research. The study population was all stocks that were consistently included in the Indonesian Sharia Stock Index (ISSI), amounting to 207 stocks. The number of samples of this study was 136 stocks using the Slovin method. The results show that there are 54 stocks that meet the criteria for optimal portfolio formation. The optimal portfolio of ISSI index stocks has a portfolio return rate of $21.95 \%$ and a portfolio risk of $10.49 \%$. The portfolio performance based on the Treynor index shows that the best of the 54 stocks is PTSP shares amounting to $32.73 \%$ of the trading sector. While the results in determining investment decisions using the Capital Asset Pricing Model (CAPM) method and 136 company shares, there are 65 undervalued stocks, and 71 stocks are overvalued.
\end{abstract}

Keywords: optimal portfolio, single index model, portfolio return, portfolio risk, treynor index, Capital Asset Pricing Model (CAPM)

Abstrak: Tujuan dari penelitian ini adalah untuk menganalisis portofolio optimal saham menggunakan model indeks tunggal dan Capital Asset Pricing Model (CAPM) dalam pengambilan keputusan investasi serta berapa keuntungan yang diharapkan dan risiko dari portofolio optimal yang terbentuk pada saham syariah di Indeks Saham Syariah Indonesia (ISSI) di Bursa Efek Indonesia periode 2016-2020. Desain penelitian ini adalah penelitian deskriptif kuantitatif. Populasi penelitian adalah seluruh saham yang konsisten tergabung dalam Indeks Saham Syariah Indonesia (ISSI) yang berjumlah 207 saham. Jumlah sampel yang digunakan dalam penelitian sebanyak 136 saham dengan pemilihan menggunakan metode slovin. Hasil penelitian menunjukkan bahwa terdapat 54 saham yang memenuhi kriteria pembentukan portofolio optimal. Portofolio optimal dari saham-saham indeks ISSI tersebut memiliki tingkat return portofolio sebesar $21,95 \%$ dan risiko portofolio sebesar $10,49 \%$. Kinerja portofolio berdasarkan treynor index menunjukkan bahwa saham yang terbaik dari 54 saham tersebut adalah saham milik PTSP sebesar $32,73 \%$ dari sektor perdagangan. Sedangkan hasil dalam menentukan keputusan investasi menggunakan metode Capital Asset Pricing Model (CAPM) dan 136 saham perusahaan terdapat 65 saham yang undervalued, dan 71 saham yang termasuk overvalued.

Kata kunci : portofolio optimal, model indeks tunggal, return portofolio, risiko portofolio, treynor index, Capital Asset Pricing Model (CAPM)

\section{PENDAHULUAN \\ Latar Belakang}

Pasar modal syariah di Indonesia mulai mendapat respon positif dan mendapat perhatian dari berbagai kalangan masyarakat. Hal tersebut dapat diketahui dari banyaknya jumlah sekuritas yang 
diperjualbelikan dengan kapitalisasi pasar yang besar serta peningkatan jumlah investor yang semakin meningkat tiap tahun (Hadi, 2015). Investor banyak yang menjatuhkan pilihan berupa investasi pada pasar modal. Hal ini disebabkan karena investasi pada pasar modal dinilai lebih menghasilkan rate of return yang lebih tinggi dibandingkan dengan investasi lain misalnya di sektor real aset maupun dipasar uang (Suroto, 2015). Adapun risiko pada portofolio terbagi menjadi dua kategori yakni risiko sistematis dan risiko non sistematis. Risiko sistematis merupakan risiko yang berpengaruh terhadap pasar secara keseluruhan. Hal ini berarti pergerakan bursa saham secara keseluruhan dapat mempengaruhi pergerakan harga saham tertentu. Sedangkan risiko non sistematis merupakan risiko yang hanya terjadi pada perusahaan tersebut. Karena hanya terjadi pada perusahaan tersebut, maka investor dapat memperkecil terjadinya risiko non sistematis dari suatu investasi saham dengan mengambil langkah berupa diversifikasi (Fahmi, 2018).

Portofolio terbagi menjadi dua jenis yaitu portofolio efisien dan portofolio optimal. Yang dimaksud dengan portofolio efisien adalah portofolio yang dapat menghasilkan tingkat keuntungan tertentu tetapi dengan risiko yang lebih rendah, atau risiko tertentu dengan tingkat keuntungan yang justru lebih tinggi (Husnan, 2003). Sedangkan portofolio optimal adalah portofolio yang dinilai paling bagus diantara berbagai portofolio pada kumpulan portofolio efisien sehingga dipilih seorang investor (Tandelilin, 2001). Seorang investor yang ingin membentuk portofolio yang optimal harus benar-benar dapat menganalisa kondisi pasar yang ada secara tepat.

Salah satu metode pemilihan portofolio yang digunakan untuk menentukan return optimal pada risiko minimal adalah dengan menggunakan model indeks tunggal. Model indeks tunggal didasarkan pada pengamatan harga dari suatu sekuritas yang berubah searah dengan indeks harga pasar (Hartono, 2017). Teknik analisis portofolio optimal dengan menggunakan model indeks tunggal dilakukan dengan cara membandingkan Excess Return to Beta (ERB) dengan Cut of Rate $\left(\mathrm{C}_{\mathrm{i}}\right)$ dari masing-masing saham. Saham yang mempunyai Excess Return to Beta (ERB) lebih besar dari Cut of Rate $\left(\mathrm{C}_{\mathrm{i}}\right)$ dapat digunakan sebagai calon kandidat portofolio, sedangkan jika Cut of Rate $\left(\mathrm{C}_{\mathrm{i}}\right)$ lebih besar dari Excess Return to Beta (ERB) maka saham tidak dapat dikategorikan ke dalam portofolio (Darmawan dan Purnawati, 2015).

Kinerja portofolio saham juga perlu dianalisis terlebih dahulu agar para investor dapat mengetahui portofolio mana yang memiliki kinerja yang baik, sehingga nantinya dapat dijadikan pertimbangan dalam mengambil keputusan saat berinvestasi. Evaluasi terhadap kinerja portofolio dengan menggunakan risk adjusted terbagi menjadi tiga cara yaitu, yaitu indeks sharpe, treynor index dan indeks Jensen. Dari ketiga cara pengukuran tersebut, peneliti memilih menggunakan treynor index karena dengan cara ini portofolio sudah terdiversifikasi dengan baik sehingga risiko yang dianggap relevan terjadi adalah risiko sistematis yang pengukurannya dilakukan dengan beta (Tandelilin, 2010).

Selain menganalisis kinerja portofolio untuk mengetahui kinerja yang baik, peneliti juga menggunakan metode untuk menilai kelayakan investasi portofolio dengan memperhitungkannya menggunakan estimasi Capital Asset Pricing Model (CAPM). Tujuan peneliti menggunakan metode CAPM adalah untuk memahami jenis saham yang termasuk undervalued (membeli saham) dan overvalued (menjual saham), sebagai pertimbangan pengambilan keputusan investasi dengan melihat tingkat return dan risiko sahamnya.

Obyek penelitian ini menggunakan saham syariah yang terdaftar dalam Indeks Saham Syariah Indonesia (ISSI). Alasan dalam mengambil objek Indeks Saham Syariah Indonesia (ISSI) ini untuk memberikan peluang return maksimal yang didapatkan investor dalam berinvestasi di pasar modal syariah.

Perkembangan saham syariah mengalami peningkatan yang sangat baik setiap tahunnya. Berikut data perkembangan jumlah saham syariah di Indonesia: 


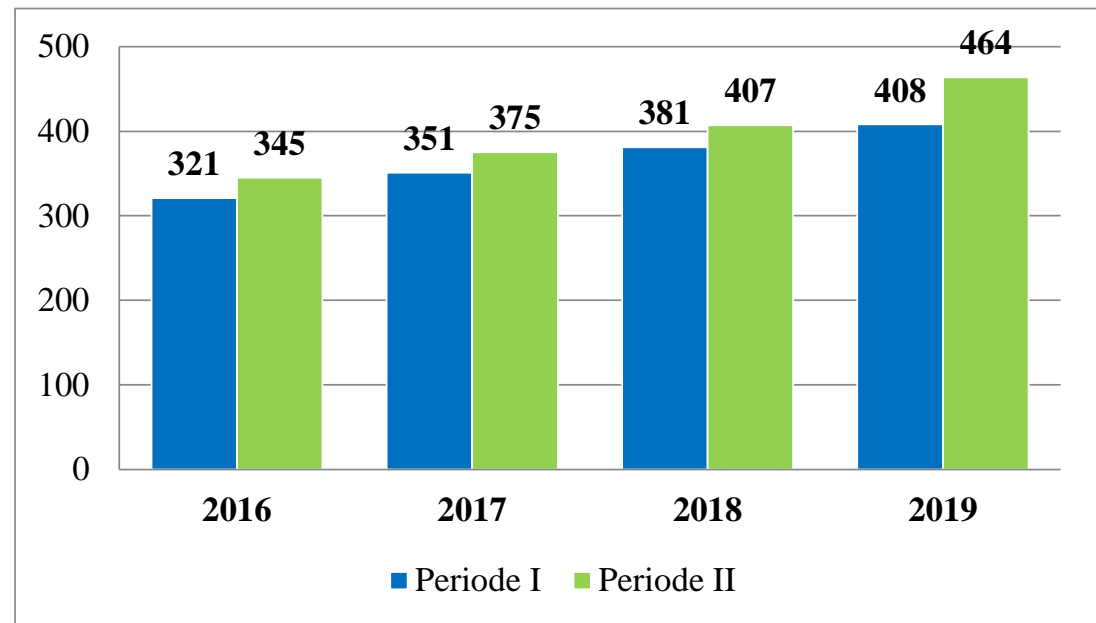

Sumber: Data OJK, 2016-2020

\section{Gambar 1}

\section{Perkembangan Saham Syariah Dalam Daftar Efek Syariah (DES)}

Gambar 1 menunjukkan perkembangan saham syariah di Indonesia yang ditetapkan oleh dewan efek syariah mulai dari 2016-2019. Grafik batang warna biru menunjukkan perkembangan saham syariah pada periode pertama, sedangkan grafik batang warna hijau menunjukkan perkembangan saham syariah pada periode kedua. Perkembangan saham syariah dari tahun ke tahun mengalami perkembangan yang cukup baik.

Hasil penelitian Lestari dan Yunita menunjukkan hasil bahwa portofolio optimal yang dibentuk dengan menggunakan indeks tunggal dan CAPM terjadi pada portofolio empat perusahaan di sektor perbankan. Selain itu, model indeks tunggal juga memiliki hasil evaluasi kinerja lebih baik dibandingkan model CAPM (Lestari dan Yunita, 2019). Sedangkan penelitian mengenai keputusan dalam investasi dengan metode Capital Asset Pricing Model (CAPM) oleh Puta dan Yadnya menunjukkan bahwa terdapat 15 saham perusahaan yang termasuk undervalued. Hal ini dikarenakan saham tersebut memiliki tingkat pengembalian saham individu yang lebih besar dari tingkat pengembalian yang diharapkan. Keputusan yang diambil untuk saham undervalued adalah dengan membeli saham tersebut (Putra dan Yadnya, 2016).

Berdasarkan latar belakang tersebut, maka perlu diteliti mengenai penggunaan model indeks tunggal dan CAPM dalam menentukan portofolio optimal pada Indeks Saham Syariah Indonesia (ISSI). Hal ini disebabkan tingginya minat kaum millennial untuk berinvestasi di pasar modal syariah sehingga perlu memperhitungkan return dan resiko dalam berinvestasi (Hati dan Harefa, 2019). Oleh karena itu, penelitian ini dilakukan untuk mengetahui bagaimana cara menentukan portofolio optimal dengan menggunakan model indeks tunggal, bagaimana penggunaan Capital Asset Pricing Model (CAPM) dalam pengambilan keputusan investasi serta berapa keuntungan yang diharapkan dan risiko dari portofolio optimal yang terbentuk pada saham syariah di Indeks Saham Syariah Indonesia (ISSI) di Bursa Efek Indonesia periode 2016-2020.

\section{Investasi}

Investasi adalah menanamkan dana dengan tujuan mendapatkan tambahan atau keuntungan tertentu atas uang atau dana tersebut. Dengan demikian, investasi yaitu kegitaan menunda konsumsi untuk mendapatkan nilai konsumsi yang lebih besar pada masa yang akan datang (Umam dan Sutanto, 2017). 


\section{Return (Tingkat Pengembalian)}

Return merupakan hasil yang didapatkan dari investasi. Return ini dibedakan menjadi dua yaitu, return realisasi dan return ekspektasi. Return yang diharapkan dari portofolio merupakan rata-rata tertimbang dari return ekpektasi masing-masing sekuritas tunggal (Syulviya, 2015).

\section{Risiko}

Risiko dapat didefinisikan sebagai bentuk kondisi yang belum pasti tentang suatu keadaan yang akan terjadi yang berkaitan dengan keputusan yang akan diambil berdasarkan berbagai pertimbangan tertentu pada saat ini. Investasi selalu berkaitan dengan risiko. Seperti pendapat yang dikemukakan oleh Raharjo bahwa risiko adalah apabila investasi yang diharapkan ternyata hasilnya tidak sesuai dengan harapan (Fahmi, 2018).

\section{Teori Portofolio}

Portofolio adalah bidang ilmu khusus yang mengkaji tentang bagaimana cara yang dilakukan oleh seorang investor dalam menurunkan risiko berinvestasi secara minimal mungkin (Fahmi, 2018). Secara umum, portofolio merupakan sekumpulan investasi dari sejumlah aset dengan tingkat keuntungan dan risiko yang berbeda dalam jangka waktu tertentu. Sedangkan pengertian portofolio optimal merupakan portofolio gabungan dari return ekspektasi dengan risiko minimal (Hartono, 2017).

\section{Model Indeks Tunggal}

Model indeks tunggal merupakan teknik untuk mengukur return dan risiko saham atau portofolio (Hartono, 2017). Model ini memperhitungkan pergerakan return saham yang hanya berkaitan dengan pergerakan pasar (Zubir, 2013). Cara untuk menentukan portofolio optimal adalah membandingkan nilai dari excess return to beta (ERB) dengan cut-off-rate (Ci), dihitung menggunakan rumus sebagai berikut (Hartono, 2017):

$$
E R B_{i}=\frac{E\left(R_{i}\right)-R_{B R}}{\beta_{i}}
$$

Keterangan:

ERBi

$=$ Excess return to beta sekuritas ke-i

$\mathrm{E}(\mathrm{Ri})$

RBR

= Expected return berdasarkan model indeks tunggal untuk sekuritas ke-i

$\beta_{\mathrm{i}}$ = Return aktiva bebas risiko

\section{Capital Asset Pricing Model (CAPM)}

CAPM merupakan penghubung tingkat expected return dari suatu aset berisiko dengan risiko dari aset tersebut pada kondisi pasar yang seimbang (Tandelilin, 2010). Model ini berdasarkan teori portofolio yang dijelaskan oleh Markowitz. Berdasarkan model yang dikembangkan Markowitz, masingmasing investor diasumsikan akan melakukan diversivikasi terhadap portofolionya dan memilih portofolio optimal berdasarkan preferensinya terhadap return dan risiko. Metode CAPM adalah untuk memahami jenis saham yang termasuk undervalued (membeli saham) dan overvalued (menjual saham), sebagai pertimbangan pengambilan keputusan investasi dengan melihat tingkat return dan risiko sahamnya (Kennedy dan Yanis, 2019).

\section{Treynor index}

Treynor index dikembangkan oleh Jack Treynor untuk mengukur kinerja portofolio, dan indeks ini sering disebut juga dengan reward to volatility ratio, metode ini diukur dengan cara membandingkan antara premi risiko portofolio (yaitu selisih rata-rata tingkat pengembalian portofolio dengan rata-rata bunga bebas risiko) dengan risiko portofolio yang dinyatakan dengan beta (risiko pasar atau risiko sistematis) (Halim, 2005). 


\section{Indeks Saham Syariah Indonesia (ISSI)}

Indeks Saham Syariah Indonesia (ISSI) adalah indeks saham yang menggambarkan kumpulan saham syariah yang tercatat di Bursa Efek Indonesia (BEI) dan tergabung dalam Daftar Efek Syariah (DES). Perusahaan yang tergabung dalam Indeks Saham Syariah Indonesia (ISSI) harus memiliki rasiorasio keuangan seperti total utang yang berbasis bunga tidak lebih $82 \%$ dibandingkan dengan total ekuitas. Sedangkan total pendapatan bunga dan pendapatan tidak halal lainnya dibandingkan dengan total pendapatan usaha dan pendapatan lainnya tidak boleh lebih dari 10\% (OJK, 2012).

\section{Kerangka Berfikir}

Adapun kerangka berfikir dalam penelitian ini digambarkan sebagai berikut.

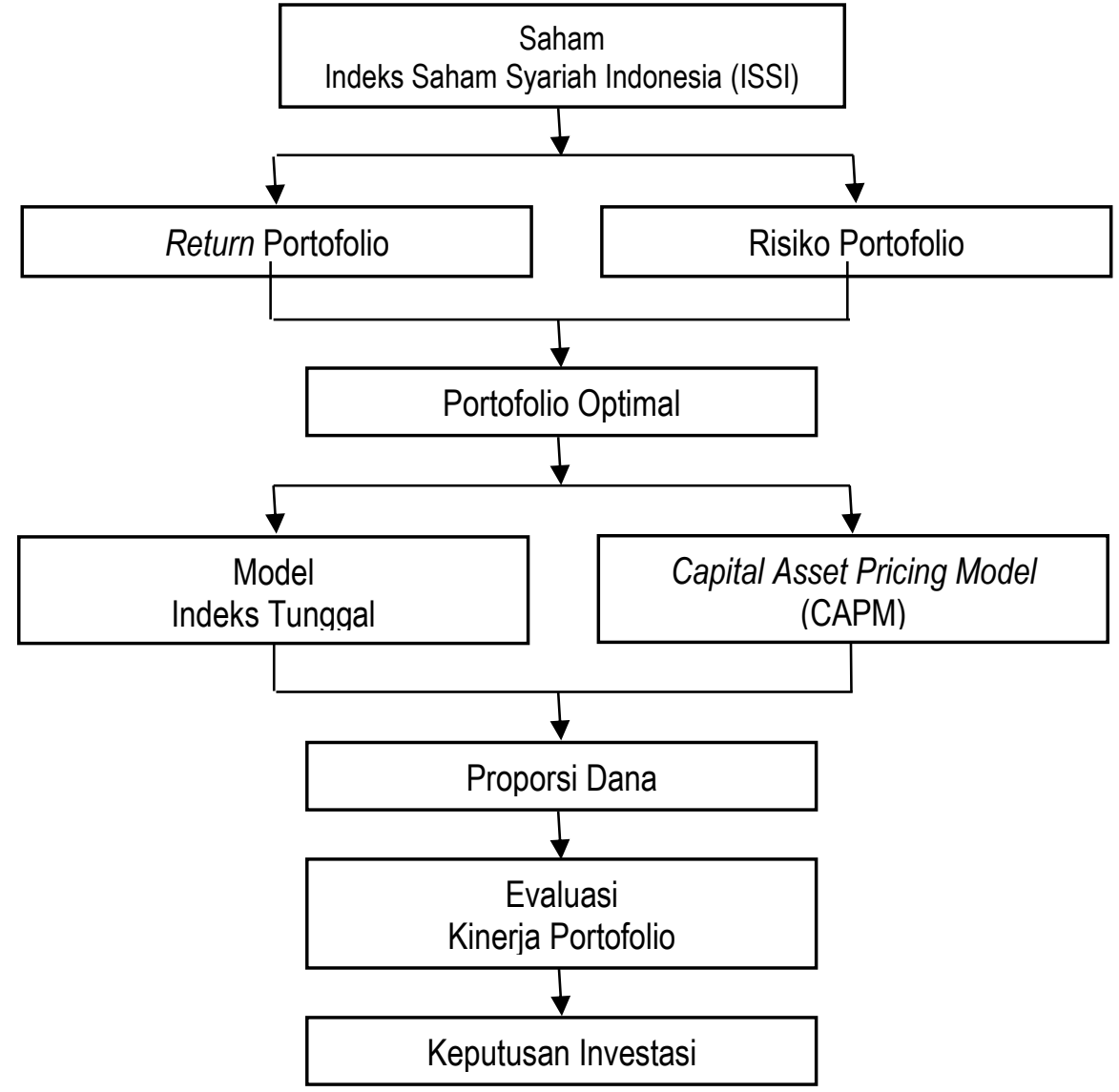

Gambar 2 : Kerangka Berfikir

Analisis portofolio dapat digunakan untuk menentukan return optimal pada risiko yang minimal, salah satu metode analisis yang digunakan adalah model indeks tunggal. Investor juga perlu melakukan keputasan investasi secara rasional dalam memilih saham yang baik, dengan tingkat return yang tinggi dan risiko yang kecil, penilitian ini juga menghitung kinerja portofolio optimal untuk mengetahui peringkat saham yang terbaik, dan juga menghitung model Capital Asset Pricing Model (CAPM) dalam menentukan harga saham yang undervalued atau overvalued, untuk mengambil sebuah keputusan investasi.

\section{METODE PENELITIAN}

Penelitian ini merupakan penelitian deskriptif dengan metode pendekatan kuantitatif. Data yang digunakan dalam penelitian ini adalah data sekunder yang diakses dari https://www.idx.co.id dan https://www.bi.go.id. Populasi penelitian ini adalah semua saham syariah yang terdaftar di Bursa Efek Indonesia dan konsisten tedaftar ke dalam Indeks Saham Syariah Indonesia (ISSI) selama periode 
Januari 2016 sampai Juni 2020 yang berjumlah 207 saham yang merupakan keseluruhan saham syariah yang terdaftar di Bursa Efek Indonesia.

Sampel adalah bagian dari jumlah dan karakteristik yang dimiliki oleh populasi. Peneliti menentukan sampel didasarkan pada perhitungan metode slovin. Rumus slovin untuk menentukan sampel yaitu sebagai berikut:

$$
n=\frac{N}{1+N(e)^{2}}
$$

Keterangan :

$$
\begin{array}{ll}
\mathrm{n} & =\text { Jumlah sampel penelitian } \\
\mathrm{N} & =\text { Jumlah populasi } \\
\mathrm{e} & =\text { Batas toleransi kesalahan }(1 \% \text { atau } 0,01,5 \% \text { atay } 0,05, \text { dan } 10 \% \text { atau } 0,1)
\end{array}
$$

Populasi yang terdapat dalam penelitian ini berjumlah 207 perusahaan dan tingkat signifikan yang dipilih yaitu 0,05 , maka besarnya sampel penelitian ini adalah sebagai berikut:

$$
\begin{aligned}
& n=\frac{207}{1+207(0,05)^{2}} \\
& n=136,40
\end{aligned}
$$

Jadi, berdasarkan perhitungan didapat jumlah keseluruhan sampel dalam penelitian ini sebanyak 136 perusahaan. Objek penelitian yang digunakan, antara lain:

Tabel 1

Sampel Penelitian

\begin{tabular}{lc}
\hline \multicolumn{1}{c}{ Nama Sektor } & Jumlah Sampel \\
\hline Pertanian & 4 Saham \\
\hline Pertambangan & 12 Saham \\
\hline Industri Dasar Dan Kimia & 20 Saham \\
\hline Industri & 12 Saham \\
\hline Barang Konsumsi & 16 Saham \\
\hline Properti & 26 Saham \\
\hline Infrastruktur & 12 Saham \\
\hline Keuangan & 1 Saham \\
\hline Perdagangan & 33 Saham \\
\hline Total & 136 Saham \\
\hline
\end{tabular}

\section{Definisi Operasional Variabel}

Variabel yang digunakan untuk membentuk portofolio optimal yaitu sebagai berikut:

1. Realized return (Ri) merupakan return yang telah terjadi (Hartono, 2017).

$$
R_{\mathrm{i}}=\frac{\left(P_{1}-P_{t-1}\right)}{P_{t-1}}
$$

Keterangan:
Pt $\quad=$ Harga saham pada periode $t$
$\mathrm{Pt}-1=$ Harga saham pada periode $\mathrm{t}-1$
$\mathrm{Pt} \quad=$ Dividen pada akhir periode

2. Expected return $\mathrm{E}(\mathrm{Ri})$, merupakan return yang diharapkan tiap saham individual.

$$
E\left(R_{\mathrm{i}}\right)=\sum_{j=1}^{n}\left(R_{i j} . P_{j}\right)
$$

Keterangan:

$E(R i)=$ Expected return suatu aktiva atau sekuritas ke-i

Rij = Hasil masa depan ke $-\mathrm{j}$ untuk sekuritas ke-i

$\mathrm{Pj}=$ = Probabilitas hasil masa depan ke-j (untuk sekuritas ke-i )

$\mathrm{n} \quad=$ Jumlah dari hasil masa depan 
3. Standar deviasi merupakan pengukuran yang digunakan untuk menghitung risiko.

$$
S D=\sqrt{\frac{\sum_{i=1}^{n}\left(X_{i}-E\left(X_{i}\right)\right)^{2}}{n}}
$$

Keterangan:
SD $\quad=$ standar deviasi
$\mathrm{Xi} \quad=$ nilai ke- $\mathrm{i}$
$\mathrm{E}(\mathrm{Xi}) \quad=$ nilai ekspektasi
$\mathrm{n} \quad=$ jumlah periode pengamatan.(Hartono, 2017: 307)

4. Variance $\left(\sigma_{i}^{2}\right)$ adalah kuadrat dari standar deviasi.

$$
\begin{aligned}
& \text { Var }=\left(\sigma_{i}^{2}\right) \\
& \quad \text { atau } \\
& \sigma_{i}^{2}=\sum_{i=1}^{n} \frac{\left(x_{i}-x\right)^{2}}{n-1}
\end{aligned}
$$

5. Beta merupakan pengukur volatilitas antara return-return suatu sekuritas (portofolio) dengan tingkat pengembalian pasar.

$$
\beta i=\frac{\sigma_{i m}}{\sigma_{m}^{2}}
$$

Keterangan:
$\beta \mathrm{i} \quad=$ beta sekuritas
$\sigma_{\mathrm{im}} \quad=$ kovarians return antara sekuritas ke I dengan return pasar
$\sigma^{2} \mathrm{~m} \quad=$ varian return pasar

6. Alpha merupakan variabel yang tidak dipengaruhi oleh return pasar (Husnan, 2003).

$$
\alpha_{i}=E\left(R_{i}\right)-\beta_{i} \cdot E(R m)
$$

Keterangan:
$a_{i} \quad=$ Alpha sekuritas
$\mathrm{E}\left(\mathrm{R}_{\mathrm{i}}\right) \quad=$ expected return dari investasi saham $\mathrm{i}$
$\mathrm{E}(\mathrm{Rm}) \quad=$ expected return pasar

7. Varian dari kesalahan residu $\left(\sigma_{\mathrm{ei}}{ }^{2}\right)$ merupakan variabel yang menunjukkan besarnya risiko sistematis yang terjadi dalam perusahaan.

${\sigma_{\varrho i}}^{2}=\sigma_{i}{ }^{2}-\beta_{i}{ }^{2} \cdot \sigma m^{2}$

Keterangan:

$$
\begin{array}{ll}
\sigma_{\mathrm{ei}}{ }^{2} & =\text { varian dari kesalahan residu } \\
\sigma_{\mathrm{i}}{ }^{2} & =\text { varian residu } \\
\beta_{\mathrm{i}}{ }^{2} & =\text { beta saham } \\
\sigma_{\mathrm{m}}{ }^{2} & =\text { varian return pasar }
\end{array}
$$

8. Return bebas risiko (RBR) merupakan return aktiva bebas risiko. RBR merupakan rata-rata dari SBIS selama periode 2016 sampai Juni 2020.

9. Excess Return to Beta (ERB) merupakan selisih expected return dengan return bebas risiko yang diukur dengan beta.(Hartono, 2017: 450)

$$
E R B_{i}=\frac{E\left(R_{i}\right)-R_{B R}}{\beta_{\mathrm{i}}}
$$

Keterangan:

$$
\begin{array}{ll}
\mathrm{E}\left(\mathrm{R}_{\mathrm{i}}\right) & =\text { expected return } \\
\mathrm{RBR} & =\text { return aktiva bebas resiko } \\
\beta_{\mathrm{i}} & =\text { beta sekuritas ke-i }
\end{array}
$$

10. Cut off rate $\left(C_{i}\right)$ merupakan nilai $C$ sekuritas ke-l yang dihitung dar kumulasi nilai -nilai $A 1$ sampai dengan $A_{i}$ dan nilai-nilai $B 1$ sampai dengan $B_{i}$. 


$$
\begin{aligned}
C_{i} & =\frac{\sigma_{M}{ }^{2} \sum_{j=1}^{n} A_{j}}{1+\sigma_{M}{ }^{2} \sum_{j=1}^{i} B_{j}} \\
A_{i} & =\frac{\left(E\left(R_{i}\right)-R_{B R}\right) \cdot \beta_{\mathrm{i}}}{\sigma_{\mathrm{ei}}{ }^{2}} \\
B_{i} & =\frac{\beta_{\mathrm{i}}{ }^{2}}{\sigma_{\mathrm{ei}}{ }^{2}}
\end{aligned}
$$

Keterangan:

$$
\begin{array}{ll}
\sigma M^{2} & =\text { varian pasar } \\
\sigma_{\mathrm{\rho}}{ }^{2} \mathrm{M} & =\text { risiko pasar } \\
\mathrm{E}(\mathrm{Ri}) & =\text { expected return } \\
\mathrm{RBR} & =\text { return aktiva bebas resiko } \\
\beta_{\mathrm{i}} & =\text { beta sekuritas ke-i }
\end{array}
$$

11. Cut-off point $\left(\mathrm{C}^{*}\right)$ adalah nilai $\mathrm{Ci}$ di mana nilai ERB terakhir kali masih lebih besar dari nilai $\mathrm{Ci}$ (Hartono, 2017).

12.Proporsi dana (Zi), masing-masing saham yang masuk ke dalam portofolio optimal dihitung proporsi dana investasinya menggunakan program microsoft excel dengan rumus IF atau dengan rumus berikut :

$$
Z i=\frac{\beta_{i}^{2}}{\sigma_{e i}{ }^{2}}\left(E R B_{i}-C^{*}\right)
$$

Keterangan :

$$
\begin{array}{ll}
\beta \mathrm{i} & =\text { beta saham } \mathrm{i} \\
\sigma \text { oi2 } & =\text { variance error saham } \mathrm{i} \\
\mathrm{ERB} & =\text { Excess Return to Beta saham } \mathrm{i} \\
\mathrm{C}^{*} & =\text { Cut-Off-Point }
\end{array}
$$

13.Proporsi sekuritas ke-i $\left(\mathrm{W}_{\mathrm{i}}\right)$

$W_{i}$ merupakan proporsi dana masing-masing saham dari portofolio optimal.

$$
W_{i}=\frac{Z_{i}}{\sum_{j=1}^{k} z_{j}}
$$

Keterangan :

$$
\begin{array}{ll}
\mathrm{Wi} & =\text { proporsi dana saham } \mathrm{i} \\
\mathrm{Zi} & =\text { proporsi dana saham } \mathrm{i} \\
\mathrm{ZZi} & =\text { jumlah } \mathrm{Xi}
\end{array}
$$

14.Beta portofolio $(\beta \rho)$ merupakan rata-rata tertimbang dari beta masing-masing sekuritas.

$$
\beta_{P}=\sum_{i=1}^{n} w_{\mathrm{i}} \cdot \beta_{\mathrm{i}}
$$

15.Alpha portofolio merupakan rata-rata tertimbang dari alpha masing-masing sekuritas

$$
\alpha_{P}=\sum_{i=1}^{n} w_{\mathrm{i}} \cdot \beta_{\mathrm{i}}
$$

16. Expected return portofolio $(E(R p))$ merupakan rata-rata tertimbang dari return individual masingmasing saham pembentuk portofolio (Tandelilin, 2001).

$E(R p)=\alpha_{P}+\beta_{P} \cdot E\left(R_{M}\right)$

Keterangan:

$$
\begin{array}{ll}
\mathrm{aP} & =\text { alpha portofolio } \\
\beta \mathrm{P} & =\text { beta portofolio } \\
\mathrm{E}(\mathrm{RM}) & =\text { return ekspektasi pasar }
\end{array}
$$

17. Risiko portofolio $\left(\sigma P^{2}\right)$ merupakan varian return sekuritas yang membentuk portofolio (Hartono, 2017).

$$
\sigma_{P}^{2}=\beta_{P}^{2} \cdot \sigma_{M}^{2}+\left(\sum_{j=1}^{n} w_{i} \cdot \sigma_{\mathrm{ei}}\right)^{2}
$$




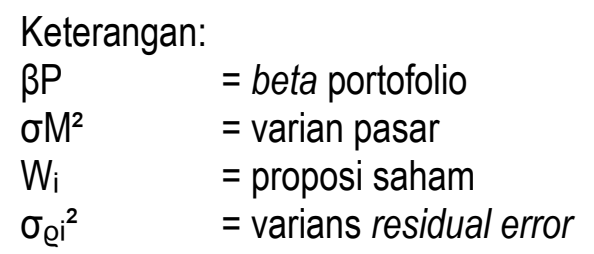

18. Treynor index merupakan ukuran kinerja portofolio dengan cara membandingkan antara rata-rata tingkat pengembalian bunga bebas risiko dengan beta portofolio atau risiko pasar (Halim, 2005).

$$
T p i=\frac{R p i-R f}{\beta p i}
$$

Keterangan:

$\begin{array}{ll}\text { Tpi } & =\text { treynor index portofolio } \\ \mathrm{Rpi} & =\text { rata-rata tingkat pengembalian portofolio } \mathrm{i} \\ \mathrm{Rf} & =\text { rata-rata return bebas risiko } \\ \mathrm{Bp}_{\mathrm{i}} & =\text { beta portofolio } \\ \mathrm{Rpi}-\mathrm{Rf} & =\text { premi risiko portofolio } \mathrm{i}\end{array}$

19. Capital Asset Pricing Model (CAPM) merupakan metode penetapan harga aktiva equilibrium yang menyatakan bahwa expected return atas sekuritas tertentu adalah fungsi linier positif dari sensitivitas sekuritas terhadap perubahan return portofolio pasarnya (Suryani dan Hendryadi, 2016).

$$
E(R i)=R f+(R m-R f) \cdot \beta i
$$

Keterangan:

$\begin{array}{ll}\mathrm{E}(\mathrm{Ri}) & =\text { expected return } \mathrm{i} \\ \mathrm{Rf} & =\text { return bebas risiko } \\ \mathrm{Bi} & =\text { beta saham } \mathrm{i} \\ \mathrm{Rm} & =\text { return pasar }\end{array}$

\section{Teknik Pengumpulan Data}

Teknik pengumpulan data pada penelitian ini adalah studi dokumentasi. Data yang digunakan merupakan data sekunder yaitu data closing price saham yang terdapat di Bursa Efek Indonesia melalui www.idx.co.id pada periode 2016-2020.

\section{Teknik Analisis Data}

Dalam menentukan portofolio optimal penelitian ini menggunakan model indeks tunggal. Sedangkan perhitungannya dilakukan dengan menggunakan progam Microsoft Excel. Adapun langkahlangkah dalam analisis penelitian adalah:

1. Mengumpulkan data-data saham perusahaan yang secara berturut-turut terdaftar dalam 9 (sembilan) periode Indeks Saham Syariah Indonesia (ISSI) di Bursa Efek Indonesia yaitu periode Desember 2015-Mei 2016, Juni 2016-November 2016, Desember 2016-Mei 2017, Juni 2017-November 2017, Desember 2017-Mei 2018, Juni 2018-November 2018, Desember 2018-Mei 2019, Juni 2019November 2019, Desember 2019-Mei 2020.

2. Menghitung realized return $\left(\mathrm{R}_{\mathrm{i}}\right)$ dari masing-masing saham serta pasar Indeks Saham Syariah Indonesia (ISSI).

3. Menghitung expected return $\left(E\left(R_{i}\right)\right)$ dari masing-masing saham serta pasar Indeks Saham Syariah Indonesia (ISSI).

4. Menghitung standar deviasi (SD) dari masing-masing saham serta pasar Indeks Saham Syariah Indonesia (ISSI).

5. Menghitung Variance $\left(\sigma_{i}^{2}\right)$ dari masing-masing saham serta pasar (JII).

6. Menghitung Beta $\left(\beta_{i}\right)$ dan Alpha $\left(\alpha_{i}\right)$ masing-masing saham.

7. Menghitung varian dari kesalahan residu $\left(\sigma_{\mathrm{ei}}{ }^{2}\right)$ masing-masing saham. 
8. Menentukan tingkat pengembalian return bebas risiko (RBR)

9. Menghitung Excess Return to Beta (ERB) masing-masing saham. Nilai ERB yang diperoleh diurutkan dari nilai yang terbesar ke terkecil. Saham-saham yang memiliki nilai ERB lebih besar atau sama dengan ERB di titik $\mathrm{C}^{*}$, maka saham tersebut merupakan kandidat portofolio.

10.Menghitung Cut Off Rate $\left(\mathrm{C}_{\mathrm{i}}\right)$

11.Menentukan Cut Off Point $\left(C^{*}\right)$.

12.Menentukan proporsi dana masing-masing saham pembentuk portofolio berdasarkan model indeks tunggal.

13. Menghitung beta portofolio $(\beta \rho)$ dan alpha portofolio ( $\alpha \rho)$.

14.Menentukan Expected Return Portofolio (E(Rp)).

15. Menentukan risiko portofolio $\left(\sigma P^{2}\right)$.

16.Menghitung evaluasi kinerja portofolio dengan treynor index untuk mengetahui peringkat saham.

17.Menghitung Capital Asset Pricing Model (CAPM) untuk menentukan keputusan investasi untuk membeli saham (undervalued) atau menjual saham (overvalued).

\section{HASIL DAN PEMBAHASAN}

Pembentukan portofolio optimal menggunakan model indeks tunggal. Model indeks tunggal memperlihatkan semakin besar return yang diperoleh maka risiko saham individual yang ditanggung akan lebih besar daripada risiko portofolio yang dimiliki. Langkah awal peneliti menghitung realized return, expected return, standar deviasi, dan varian masing-masing saham. Setelah itu menghitung Beta, Alpha, dan varian error residual. Pembentukan portofolio optimal dilakukan dengan menyusun peringkat excess return to beta dari nilai yang tertinggi ke terendah. Penentuan ERB ini memerlukan analisis terhadap expected return, beta, dan risk free. Setelah penentuan ERB, selanjutnya menentukan cut off rate (Ci) dilakukan dengan menganalisis hasil terhadap hasil perhitungan expected return, variance market, beta alpha, variance error residual, dan risk free rate.

Hasil perhitungan menunjukkan saham yang mempunyai tingkat expected return paling besar adalah saham VOKS dari sektor industri sebesar 0,11824, dan saham yang memiliki expected return paling rendah yaitu saham MPPA dari sektor perdagangan sebesar $-0,03337$. Risiko dari expected return saham dapat diketahui menggunakan varian. Saham yang mempunyai tingkat varian paling besar adalah saham VOKS dari sektor industri sebesar 0,56773. Sedangkan saham yang mempunyai varian paling kecil adalah saham IATA dari sektor infrastruktur sebesar 0,00091. Sedangkan, untuk nilai expected return pasar sebesar 0,00075 dengan risiko 0,03851, dan nilai risk free rate (Rf) sebesar 0,0833\%. Expected return market yang bernilai positif ini membuktikan bahwa investasi di pasar modal memberikan return bagi investor.

Tabel 2

Perhitungan Beta, Alpha, Variance Error Residual dan Excess Retur to Beta

\begin{tabular}{|c|c|c|c|c|c|c|c|c|}
\hline No. & Nama Sektor & $\begin{array}{l}\text { Kode } \\
\text { Saham }\end{array}$ & $\begin{array}{l}\text { Beta } \\
\text { (Bi) }\end{array}$ & $\begin{array}{l}\text { Alpha } \\
\text { (ai) }\end{array}$ & $\alpha \mathrm{e}^{2}$ & ERB & $\mathrm{Ci}$ & Keputusan \\
\hline 1. & \multirow{4}{*}{ Pertanian } & AALI & 1,78558 & $-0,00531$ & 0,00850 & $-0,04887$ & $-0,017$ & Tidak Optimal \\
\hline 2. & & $\mathrm{BISI}$ & $-0,00373$ & $-0,00373$ & 0,01099 & 23,07362 & $-0,017$ & Optimal \\
\hline 3. & & ANJT & 0,49087 & $-0,01899$ & 0,00608 & $-0,20764$ & $-0,024$ & Tidak Optimal \\
\hline 4. & & LSIP & 0,98500 & $-0,00284$ & 0,01230 & $-0,08670$ & $-0,029$ & Tidak Optimal \\
\hline 5. & \multirow{3}{*}{ Pertambangan } & ADRO & 1,61086 & 0,01736 & 0,00938 & $-0,04018$ & $-0,031$ & Tidak Optimal \\
\hline 6. & & ANTM & 2,05245 & 0,02205 & 0,01971 & $-0,02909$ & $-0,031$ & Optimal \\
\hline 7. & & BSSR & 0,00510 & 0,01253 & 0,01679 & $-13,87334$ & $-0,031$ & Tidak Optimal \\
\hline
\end{tabular}




\begin{tabular}{|c|c|c|c|c|c|c|c|c|}
\hline 8. & & DSSA & $-0,42170$ & 0,01680 & 0,01679 & 0,15845 & $-0,029$ & Optimal \\
\hline 9. & & GEMS & 0,05932 & 0,01496 & 0,00812 & $-1,15124$ & $-0,030$ & Tidak Optimal \\
\hline 10. & & HRUM & 1,20586 & 0,02478 & 0,03576 & $-0,04777$ & $-0,030$ & Tidak Optimal \\
\hline 11. & & INCO & 1,76938 & 0,01900 & 0,01728 & $-0,03559$ & $-0,031$ & Tidak Optimal \\
\hline 12. & & ITMG & 1,77694 & 0,01506 & 0,02198 & $-0,03765$ & $-0,031$ & Tidak Optimal \\
\hline 13. & & MBAP & 0,70739 & 0,01277 & 0,01372 & $-0,09896$ & $-0,032$ & Tidak Optimal \\
\hline 14. & & $\mathrm{MYOH}$ & 0,35651 & 0,01666 & 0,00902 & $-0,18617$ & $-0,033$ & Tidak Optimal \\
\hline 15. & & PTBA & $-1,00340$ & 0,07877 & 0,30438 & 0,00527 & $-0,033$ & Optimal \\
\hline 16. & & TOBA & 0,59501 & 0,06306 & 0,23227 & $-0,03326$ & $-0,033$ & Optimal \\
\hline 17. & \multirow{32}{*}{$\begin{array}{l}\text { Industri Dasar } \\
\text { Dan Kimia }\end{array}$} & ADMG & 1,40243 & 0,01294 & 0,02334 & $-0,04942$ & $-0,034$ & Tidak Optimal \\
\hline 18. & & ARNA & 0,85894 & $-0,00224$ & 0,00574 & $-0,09884$ & $-0,038$ & Tidak Optimal \\
\hline 19. & & BRPT & 2,46735 & 0,09092 & 0,05115 & 0,00384 & $-0,036$ & Optimal \\
\hline 20. & & CPIN & 1,05408 & 0,01846 & 0,00903 & $-0,06076$ & $-0,037$ & Tidak Optimal \\
\hline 21. & & CTBN & 0,33722 & $-0,01263$ & 0,00254 & $-0,28373$ & $-0,041$ & Tidak Optimal \\
\hline 22. & & EKAD & 0,88302 & 0,01943 & 0,00379 & $-0,07157$ & $-0,043$ & Tidak Optimal \\
\hline 23. & & FPNI & 2,09393 & 0,03960 & 0,19249 & $-0,02012$ & $-0,043$ & Optimal \\
\hline 24. & & GDST & 0,20495 & 0,01594 & 0,04660 & $-0,32789$ & $-0,043$ & Tidak Optimal \\
\hline 25. & & IMPC & 0,13949 & 0,00609 & 0,00152 & $-0,55275$ & $-0,045$ & Tidak Optimal \\
\hline 26. & & INTP & 1,27585 & $-0,00766$ & 0,00757 & $-0,07054$ & $-0,047$ & Tidak Optimal \\
\hline 27. & & IPOL & 1,27342 & 0,00378 & 0,00724 & $-0,06169$ & $-0,048$ & Tidak Optimal \\
\hline 28. & & $\mathrm{KDSI}$ & 1,24144 & 0,03379 & 0,01755 & $-0,03913$ & $-0,048$ & Optimal \\
\hline 29. & & KIAS & 0,09120 & $-0,00889$ & 0,00397 & $-1,01002$ & $-0,049$ & Tidak Optimal \\
\hline 30. & & $\mathrm{PICO}$ & 1,79009 & 0,07609 & 0,29449 & $-0,00327$ & $-0,048$ & Optimal \\
\hline 31. & & SMBR & 3,00458 & 0,02898 & 0,05975 & $-0,01732$ & $-0,047$ & Optimal \\
\hline 32. & & TOTO & 0,72741 & $-0,01978$ & 0,00288 & $-0,14096$ & $-0,052$ & Tidak Optimal \\
\hline 33. & & TPIA & 1,96173 & 0,05695 & 0,03210 & $-0,01268$ & $-0,051$ & Optimal \\
\hline 34. & & TRST & $-0,13178$ & 0,00619 & 0,00423 & 0,58591 & $-0,050$ & Optimal \\
\hline 35. & & UNIC & 0,38269 & 0,02930 & 0,03842 & $-0,14037$ & $-0,050$ & Tidak Optimal \\
\hline 36. & & WTON & 1,44146 & $-0,01416$ & 0,01065 & $-0,06685$ & $-0,051$ & Tidak Optimal \\
\hline 37. & & ASII & 1,50345 & $-0,00210$ & 0,00277 & $-0,05605$ & $-0,052$ & Tidak Optimal \\
\hline 38. & & AUTO & 1,10340 & $-0,00819$ & 0,00555 & $-0,08216$ & $-0,053$ & Tidak Optimal \\
\hline 39. & & BOLT & 0,08063 & $-0,00019$ & 0,00848 & $-1,03479$ & $-0,053$ & Tidak Optimal \\
\hline 40. & & BRAM & 0,72686 & 0,03254 & 0,05472 & $-0,06909$ & $-0,053$ & Tidak Optimal \\
\hline 41. & & INDR & 0,06538 & 0,04525 & 0,07570 & $-0,58113$ & $-0,053$ & Tidak Optimal \\
\hline 42. & & INDS & 1,27522 & 0,01329 & 0,02732 & $-0,05414$ & $-0,053$ & Tidak Optimal \\
\hline 43. & & KBLI & 1,14903 & 0,03439 & 0,03141 & $-0,04181$ & $-0,053$ & Optimal \\
\hline 44. & & MASA & $-0,81546$ & 0,02580 & 0,03699 & 0,07126 & $-0,053$ & Optimal \\
\hline 45. & & SCCO & 0,49618 & 0,01965 & 0,00723 & $-0,12754$ & $-0,053$ & Tidak Optimal \\
\hline 46. & & SMSM & 0,54526 & 0,00058 & 0,00616 & $-0,15094$ & $-0,054$ & Tidak Optimal \\
\hline 47. & & TFCO & 2,33817 & 0,00407 & 0,04053 & $-0,03313$ & $-0,054$ & Optimal \\
\hline 48. & & VOKS & 4,20297 & 0,11506 & 0,54153 & 0,00831 & $-0,053$ & Optimal \\
\hline 49. & \multirow{3}{*}{$\begin{array}{c}\text { Barang } \\
\text { Konsumsi }\end{array}$} & DVLA & 0,10060 & 0,01068 & 0,00248 & $-0,72105$ & $-0,054$ & Tidak Optimal \\
\hline 50. & & ICBP & 0,44299 & 0,00754 & 0,00335 & $-0,17028$ & $-0,055$ & Tidak Optimal \\
\hline 51. & & IIKP & 0,46018 & $-0,02529$ & 0,02072 & $-0,23522$ & $-0,055$ & Tidak Optimal \\
\hline
\end{tabular}




\begin{tabular}{|c|c|c|c|c|c|c|c|c|}
\hline 52. & & INAF & $-0,46255$ & 0,09653 & 0,16723 & $-0,02785$ & $-0,055$ & Optimal \\
\hline 53. & & INDF & 0,79177 & 0,00627 & 0,00436 & $-0,09654$ & $-0,056$ & Tidak Optimal \\
\hline 54. & & KAEF & $-0,85209$ & 0,03497 & 0,08593 & 0,05748 & $-0,056$ & Optimal \\
\hline 55. & & KLBF & 1,08426 & 0,00331 & 0,00289 & $-0,07302$ & $-0,057$ & Tidak Optimal \\
\hline 56. & & MERK & 0,96846 & $-0,01307$ & 0,00738 & $-0,09875$ & $-0,058$ & Tidak Optimal \\
\hline 57. & & MYOR & 0,17848 & 0,01366 & 0,00478 & $-0,38945$ & $-0,058$ & Tidak Optimal \\
\hline 58. & & ROTI & 0,49988 & 0,00054 & 0,00375 & $-0,16480$ & $-0,060$ & Tidak Optimal \\
\hline 59. & & SIDO & 1,07458 & 0,03454 & 0,01967 & $-0,04462$ & $-0,059$ & Optimal \\
\hline 60. & & SKLT & 0,27016 & 0,03567 & 0,02456 & $-0,17556$ & $-0,059$ & Tidak Optimal \\
\hline 61. & & TCID & 0,05103 & $-0,01309$ & 0,00300 & $-1,88798$ & $-0,060$ & Tidak Optimal \\
\hline 62. & & TSPC & 0,87362 & $-0,00210$ & 0,00483 & $-0,09700$ & $-0,061$ & Tidak Optimal \\
\hline 63. & & ULTJ & $-0,12927$ & 0,01956 & 0,00904 & 0,49383 & $-0,060$ & Optimal \\
\hline 64. & & UNVR & 0,70550 & 0,00261 & 0,00332 & $-0,11361$ & $-0,062$ & Tidak Optima \\
\hline 65. & \multirow{26}{*}{ Properti } & ADHI & 1,81383 & $-0,01698$ & 0,01018 & $-0,05453$ & $-0,061$ & Optimal \\
\hline 66. & & APLN & 1,66606 & $-0,01215$ & 0,01493 & $-0,05653$ & $-0,061$ & Optimal \\
\hline 67. & & ASRI & 1,77490 & $-0,01363$ & 0,00663 & $-0,05386$ & $-0,061$ & Optimal \\
\hline 68. & & BEST & 2,13179 & $-0,00939$ & 0,01326 & $-0,04273$ & $-0,060$ & Optimal \\
\hline 69. & & BKSL & 1,12774 & 0,00832 & 0,02375 & $-0,06573$ & $-0,060$ & Tidak Optimal \\
\hline 70 & & BSDE & 1,40767 & $-0,01318$ & 0,00510 & $-0,06779$ & $-0,060$ & Tidak Optimal \\
\hline 71. & & CTRA & 1,66798 & $-0,00867$ & 0,01049 & $-0,05438$ & $-0,060$ & Optimal \\
\hline 72. & & DILD & 0,26515 & $-0,01436$ & 0,00691 & $-0,36758$ & $-0,061$ & Tidak Optimal \\
\hline 73. & & DMAS & 1,64924 & 0,00128 & 0,00913 & $-0,04898$ & $-0,060$ & Optimal \\
\hline 74. & & DUTI & 0,52093 & 0,01243 & 0,04148 & $-0,13529$ & $-0,060$ & Tidak Optimal \\
\hline 75. & & GMTD & $-0,35000$ & 0,01845 & 0,00576 & 0,18604 & $-0,060$ & Optimal \\
\hline 76. & & INPP & 0,56160 & 0,01573 & 0,01023 & $-0,11956$ & $-0,060$ & Tidak Optimal \\
\hline 77. & & JKON & 0,10599 & $-0,01074$ & 0,00586 & $-0,88655$ & $-0,060$ & Tidak Optimal \\
\hline 78. & & JRPT & 1,05245 & $-0,00682$ & 0,00928 & $-0,08487$ & $-0,060$ & Tidak Optimal \\
\hline 79. & & KIJA & 1,62696 & $-0,00446$ & 0,00564 & $-0,05319$ & $-0,060$ & Optimal \\
\hline 80. & & LPCK & 2,23922 & $-0,02564$ & 0,02456 & $-0,04790$ & $-0,060$ & Optimal \\
\hline 81. & & LPKR & 1,54446 & $-0,02278$ & 0,00968 & $-0,06793$ & $-0,060$ & Tidak Optimal \\
\hline 82. & & MKPI & 0,27979 & 0,00248 & 0,00766 & $-0,28811$ & $-0,060$ & Tidak Optimal \\
\hline 83. & & MTLA & 1,02426 & 0,01504 & 0,00750 & $-0,06589$ & $-0,060$ & Tidak Optimal \\
\hline 84. & & OMRE & 2,75781 & 0,02168 & 0,04603 & $-0,02159$ & $-0,060$ & Optimal \\
\hline 85. & & PPRO & 1,51999 & 0,01402 & 0,02602 & $-0,04483$ & $-0,060$ & Optimal \\
\hline 86. & & PTPP & 2,49629 & $-0,01599$ & 0,01324 & $-0,03902$ & $-0,059$ & Optimal \\
\hline 87. & & PWON & 1,42186 & 0,00128 & 0,00732 & $-0,05693$ & $-0,059$ & Optimal \\
\hline 88. & & SMRA & 2,10423 & $-0,00973$ & 0,01329 & $-0,04346$ & $-0,058$ & Optimal \\
\hline 89. & & SSIA & 0,95501 & $-0,00307$ & 0,01698 & $-0,08969$ & $-0,058$ & Tidak Optimal \\
\hline 90. & & WIKA & 2,22575 & $-0,00331$ & 0,01331 & $-0,03816$ & $-0,058$ & Optimal \\
\hline 91. & \multirow{5}{*}{ Infrastruktur } & BIRD & 1,32502 & $-0,02530$ & 0,01421 & $-0,08120$ & $-0,058$ & Tidak Optimal \\
\hline 92. & & CASS & $-0,35389$ & $-0,02329$ & 0,01213 & 0,30194 & $-0,058$ & Optimal \\
\hline 93. & & CMNP & 0,14556 & $-0,00242$ & 0,00655 & $-0,58810$ & $-0,058$ & Tidak Optimal \\
\hline 94. & & IATA & 0,00258 & 0,00043 & 0,00091 & $-32,10753$ & $-0,058$ & Tidak Optimal \\
\hline 95. & & ISAT & 1,99539 & $-0,00498$ & 0,02116 & $-0,04349$ & $-0,058$ & Optimal \\
\hline
\end{tabular}




\begin{tabular}{|c|c|c|c|c|c|c|c|c|}
\hline 96. & & MBSS & 1,25878 & 0,01368 & 0,02440 & $-0,05455$ & $-0,058$ & Optimal \\
\hline 97. & & META & 1,08177 & 0,01071 & 0,00813 & $-0,06634$ & $-0,058$ & Tidak Optimal \\
\hline 98. & & PGAS & 2,20524 & $-0,00696$ & 0,01576 & $-0,04017$ & $-0,057$ & Optimal \\
\hline 99. & & RAJA & 1,73069 & 0,00691 & 0,04126 & $-0,04339$ & $-0,057$ & Optimal \\
\hline 100. & & SMDR & 1,50699 & 0,00468 & 0,02355 & $-0,05142$ & $-0,057$ & Optimal \\
\hline 101. & & TLKM & 0,58692 & 0,00090 & 0,00283 & $-0,13964$ & $-0,058$ & Tidak Optimal \\
\hline 102. & & WINS & 0,48242 & $-0,00237$ & 0,02032 & $-0,17683$ & $-0,058$ & Tidak Optimal \\
\hline 103. & Keuangan & PNBS & 0,33947 & $-0,02463$ & 0,01014 & $-0,31719$ & $-0,058$ & Tidak Optimal \\
\hline 104. & \multirow{33}{*}{ Perdagangan } & ACES & 0,72582 & 0,01379 & 0,00563 & $-0,09502$ & $-0,058$ & Tidak Optimal \\
\hline 105. & & AKRA & 1,68319 & $-0,01541$ & 0,00559 & $-0,05789$ & $-0,058$ & Optimal \\
\hline 106. & & ASGR & 0,27841 & $-0,01634$ & 0,00339 & $-0,35715$ & $-0,059$ & Tidak Optimal \\
\hline 107. & & BMTR & 1,56857 & $-0,02183$ & 0,02079 & $-0,06627$ & $-0,059$ & Tidak Optimal \\
\hline 108. & & CSAP & 0,20533 & $-0,00058$ & 0,00375 & $-0,40775$ & $-0,059$ & Tidak Optimal \\
\hline 109. & & ECII & 0,44841 & 0,00249 & 0,01362 & $-0,17946$ & $-0,059$ & Tidak Optimal \\
\hline 110. & & EPMT & $-0,35530$ & $-0,00469$ & 0,00776 & 0,24841 & $-0,059$ & Optimal \\
\hline 111. & & ERAA & 1,85342 & 0,03398 & 0,03818 & $-0,02586$ & $-0,059$ & Optimal \\
\hline 112. & & FAST & $-0,34652$ & 0,02267 & 0,03089 & 0,17571 & $-0,059$ & Optimal \\
\hline 113. & & FISH & 0,99351 & 0,02894 & 0,04352 & $-0,05396$ & $-0,059$ & Optimal \\
\hline 114. & & HERO & 0,12857 & $-0,00341$ & 0,00429 & $-0,67367$ & $-0,059$ & Tidak Optimal \\
\hline 115. & & JIHD & 0,08998 & $-0,00013$ & 0,00356 & $-0,92649$ & $-0,059$ & Tidak Optimal \\
\hline 116. & & JSPT & 0,45214 & 0,01287 & 0,02943 & $-0,15502$ & $-0,059$ & Tidak Optimal \\
\hline 117. & & JTPE & 0,66672 & 0,02867 & 0,01436 & $-0,08118$ & $-0,059$ & Tidak Optimal \\
\hline 118. & & KPIG & 0,56210 & $-0,00144$ & 0,00647 & $-0,15000$ & $-0,059$ & Tidak Optimal \\
\hline 119. & & LPPF & 1,98906 & $-0,03202$ & 0,01557 & $-0,05722$ & $-0,059$ & Optimal \\
\hline 120. & & LTLS & 0,83892 & 0,00125 & 0,00684 & $-0,09705$ & $-0,060$ & Tidak Optimal \\
\hline 121. & & MIKA & 0,94025 & 0,00318 & 0,00904 & $-0,08446$ & $-0,060$ & Tidak Optimal \\
\hline 122. & & MLPL & 2,46621 & $-0,01725$ & 0,02049 & $-0,04002$ & $-0,059$ & Optimal \\
\hline 123. & & MLPT & 0,26336 & 0,00705 & 0,03876 & $-0,28877$ & $-0,059$ & Tidak Optimal \\
\hline 124. & & MPPA & 1,49744 & $-0,03450$ & 0,03816 & $-0,07791$ & $-0,060$ & Tidak Optimal \\
\hline 125. & & MTDL & 0,88794 & 0,01633 & 0,00482 & $-0,07467$ & $-0,060$ & Tidak Optimal \\
\hline 126. & & PDES & 0,98795 & 0,06177 & 0,20631 & $-0,02104$ & $-0,060$ & Optimal \\
\hline 127. & & PJAA & 1,29623 & $-0,02078$ & 0,00521 & $-0,07954$ & $-0,060$ & Tidak Optimal \\
\hline 128. & & PTSP & $-0,05059$ & $-0,01472$ & 0,00303 & 1,93841 & $-0,060$ & Optimal \\
\hline 129. & & SHID & 0,16556 & 0,04531 & 0,02186 & $-0,22873$ & $-0,060$ & Tidak Optimal \\
\hline 130. & & SILO & 0,37558 & $-0,00261$ & 0,01721 & $-0,22799$ & $-0,060$ & Tidak Optimal \\
\hline 131. & & SONA & $-0,42964$ & 0,03481 & 0,08096 & 0,11362 & $-0,060$ & Optimal \\
\hline 132. & & SRAJ & $-0,20126$ & $-0,00852$ & 0,02019 & 0,45700 & $-0,060$ & Optimal \\
\hline 133. & & TGKA & 0,56399 & 0,02763 & 0,03260 & $-0,09795$ & $-0,060$ & Tidak Optimal \\
\hline 134. & & TURI & $-0,12927$ & 0,01956 & 0,00904 & 0,49383 & $-0,060$ & Optimal \\
\hline 135. & & UNTR & 0,55894 & 0,00238 & 0,00616 & $-0,14402$ & $-0,060$ & Tidak Optimal \\
\hline 136. & & WICO & $-0,20963$ & 0,07230 & 0,07843 & 0,05321 & $-0,060$ & Optimal \\
\hline
\end{tabular}

Sumber : Hasil Data Diolah

Kriteria dalam menentukan portofolio optimal adalah membandingkan nilai ERB dan $\mathrm{Ci}$ dari masing-masing saham. Apabila nilai ERB lebih besar atau sama dengan Ci maka saham-saham masuk 
kandidat portofolio optimal. Tetapi apabila nilai ERB lebih kecil dari Ci maka saham-saham tersebut tidak masuk kandidat portofolio optimal. Kelebihan menggunakan Ci dan ERB dalam menentukan portofolio optimal adalah untuk mempertimbangkan risiko sistematis saham yang diukur dengan beta. Investasi pada saham selalu mengandung risiko, baik risiko sistematis maupun risiko tidak sistematis. Risiko sistematis memang tidak dapat dihindari akan tetapi investor dapat memperkecil risiko dengan cara memilih saham-saham yang mempunyai nilai excess return to beta yang dapat dimanfaatkan untuk mempertimbangkan alternatif investasi dan mengoptimalkan penyusunan portofolio optimal. Sedangkan risiko tidak sistematis dapat ditanggulangi oleh investor dengan cara diversifikasi yaitu dengan pembentukan portofolio optimal. Investor secara rasional akan memilih saham yang memiliki return tinggi.

Berdasarkan hasil perhitungan dari 136 sampel penelitian terdapat 54 saham yang menjadi kandidat portofolio optimal. Dari 54 saham-saham Indeks Saham Syariah Indonesia (ISSI) tersebut memiliki tingkat keuntungan (return) yang tinggi dibandingkan saham-saham yang tidak masuk ke dalam kandidat portofolio optimal. Investor dapat menanamkan modalnya pada 54 saham ini, untuk dijadikan alternatif dalam berinvestasi. Hasil penelitian ini menghasilkan pilihan saham untuk berinvestasi lebih banyak dibandingkan dengan penelitian sebelumnya yang dilakukan oleh Utomo (2016) sebanyak 6 saham pembentuk portofolio optimal dan penelitian Wisambudi (2014) hanya menghasilkan 4 saham yang termasuk dalam portofolio optimal. Hal ini dapat memberikan pilihan untuk investor dalam berinvestasi di saham.

\section{Proporsi Dana Portofolio Optimal}

Berdasarkan hasil perhitungan proposi dana yang membentuk portofolio optimal saham diketahui bahwa proporsi dana terbesar yaitu pada saham PTSP dari sektor perdagangan sebesar $14 \%$. Sedangkan proporsi dana terkecil yaitu pada saham BRPT dari sektor industri dasar dan kimia sebesar $0,45 \%$. Proporsi dana terbesar merupakan alternatif investasi yang baik untuk dipilih investor, karena saham tersebut juga mempunyai nilai ERB yang lebih besar dari $\mathrm{Ci}$.

Proporsi dana dari 54 saham kandidat portofolio optimal ini, menentukan skala tertimbang terlebih dahulu untuk menentukan proporsi yang akan investor investasikan. Saham-saham kandindat pembentuk portofolio optimal ini dihitung berdasarkan beta. Hal ini sejalan dengan penelitian yang dilakukan oleh Oktaviani (2015) dan Suroto (2015) dengan hasil yang menyatakan bahwa proporsi dana harus dihitung terlebih dahulu pada skala tertimbang masing-masing saham. Analisis skala tertimbang yang digunakan merupakan hasil perhitungan, beta, variance error residual, excess return to beta, dan penentuan cut off point. Setelah didapat skala tertimbang saham kemudian dibagi dengan banyaknya saham yang termasuk dalam kandidat saham dengan portofolio optimal.

\section{Return dan Risiko Portofolio Optimal}

Saham-saham yang menjadi kandidat portofolio optimal terdiri 54 saham yang menghasilkan expected return dan risiko terbaik. Portofolio optimal dari saham-saham Indeks Saham Syariah Indonesia (ISSI) tersebut memiliki tingkat return portofolio sebesar 0,21946 (21,95\%) dan risiko portofolio sebesar $0,1049(10,49 \%)$, dimana nilai return portofolio menunjukkan tingkat pengembalian berupa keuntungan investasi. Sedangkan nilai risiko portofolio menunjukkan kerugian yang harus dihadapi saat melakukan investasi. Risiko yang diperoleh dari pembentukan portofolio ini lebih kecil dibandingkan jika berinvestasi dengan saham individual dari hasil penelitian ini, saham-saham ISSI periode tahun 2016 sampai Juni 2020 mempunyai return yang lebih tinggi dibandingkan dengan penelitian yang dilakukan oleh Berlian Nanda Oktaviani (2015) yaitu sebesar 1,77\% dan penelitian oleh Tri Yoga Utomo (2016) sebesar 4,10\%. Selain itu risiko pada saham-saham indeks ISSI juga mempunyai risiko yang lebih tinggi dibandingkan penelitian sebelumnya yaitu sebesar 2,93\%. Investor dapat meminimalisir risiko dengan cara mendiversifikasikan investasinya kedalam beberapa lembar saham (Tandelilin, 2010). 


\section{Evaluasi Kinerja Portofolio Dengan Treynor index}

Hasil perhitungan treynor index dari 54 saham di Indeks Saham Syariah Indonesia (ISSI) periode 2016-2020, memperlihatkan saham yang terbaik adalah saham PTSP sebesar 32,73\% dan saham yang terendah yaitu saham TURI sebesar $-13,66 \%$. Hasil perhitungan kinerja portofolio menggunakan treynor index dapat diketahui di tabel 3. Dibandingkan dengan penelitian sebelumnya yang dilakukan oleh Syulvina (2015) hasil dari penelitian pada semester I terdapat 8 saham perusahaan yang terpilih dari 15 perusahaan sampel dengan nilai RVOL sebesr 0.4109 , nilai ini menunjukkan nilai yang positif. Penelitian fitriaty (2014) juga memberikan hasil perhitungan nilai RVOL sebesar 0,0490. Kinerja portofolio menggunakan treynor index dihitung dengan membagi excess return dengan volatilitas portofolio (Tandelilin, 2010).

\section{Tabel 3}

Perhitungan Evaluasi Kinerja Portofolio

\begin{tabular}{lcccc}
\hline $\begin{array}{c}\text { Kode } \\
\text { Saham }\end{array}$ & $\begin{array}{c}\text { Rata-rata } \\
\text { Return }\end{array}$ & $\begin{array}{c}\text { Standar } \\
\text { Deviasi }\end{array}$ & Beta & Treynor index (\%) \\
\hline BISI & $-0,29 \%$ & $11,41 \%$ & 1,17 & $-0,40 \%$ \\
\hline ANTM & $2,36 \%$ & $16,11 \%$ & 2,05 & $1,06 \%$ \\
\hline DSSA & $1,65 \%$ & $13,06 \%$ & $-0,42$ & $-3,48 \%$ \\
\hline PTBA & $7,80 \%$ & $55,31 \%$ & $-1,00$ & $-7,60 \%$ \\
\hline TOBA & $6,35 \%$ & $48,25 \%$ & 0,60 & $10,37 \%$ \\
\hline BRPT & $9,28 \%$ & $24,53 \%$ & 2,47 & $3,69 \%$ \\
\hline FPNI & $4,12 \%$ & $44,61 \%$ & 2,09 & $1,88 \%$ \\
\hline KDSI & $3,47 \%$ & $14,08 \%$ & 1,24 & $2,65 \%$ \\
\hline PICO & $7,74 \%$ & $54,70 \%$ & 1,79 & $4,23 \%$ \\
\hline SMBR & $3,13 \%$ & $27,05 \%$ & 3,00 & $0,98 \%$ \\
\hline TPIA & $5,84 \%$ & $19,44 \%$ & 1,96 & $2,89 \%$ \\
\hline TRST & $0,61 \%$ & $6,53 \%$ & $-0,13$ & $-3,26 \%$ \\
\hline KBLI & $3,53 \%$ & $18,27 \%$ & 1,15 & $2,91 \%$ \\
\hline MASA & $2,52 \%$ & $19,49 \%$ & $-0,82$ & $-2,87 \%$ \\
\hline TFCO & $0,58 \%$ & $22,05 \%$ & 2,34 & $0,17 \%$ \\
\hline VOKS & $11,82 \%$ & $75,35 \%$ & 4,20 & $2,77 \%$ \\
\hline INAF & $9,62 \%$ & $40,93 \%$ & $-0,46$ & $-20,40 \%$ \\
\hline KAEF & $3,43 \%$ & $29,50 \%$ & $-0,85$ & $-3,82 \%$ \\
\hline SIDO & $3,54 \%$ & $14,62 \%$ & 1,07 & $3,12 \%$ \\
\hline ULTJ & $1,95 \%$ & $9,52 \%$ & $-0,13$ & $-13,66 \%$ \\
\hline ADHI & $-1,56 \%$ & $12,27 \%$ & 1,81 & $-0,96 \%$ \\
\hline APLN & $-1,09 \%$ & $13,80 \%$ & 1,67 & $-0,76 \%$ \\
\hline ASRI & $-1,23 \%$ & $10,63 \%$ & 1,77 & $-0,79 \%$ \\
\hline BEST & $-0,78 \%$ & $14,14 \%$ & 2,13 & $-0,45 \%$ \\
\hline CTRA & $-0,74 \%$ & $12,09 \%$ & 1,67 & $-0,55 \%$ \\
\hline DMAS & $0,25 \%$ & $11,47 \%$ & 1,65 & $0,04 \%$ \\
\hline GMTD & $1,82 \%$ & $7,71 \%$ & $-0,35$ & $-4,68 \%$ \\
\hline KIJA & $-0,32 \%$ & $9,78 \%$ & 1,63 & $-0,31 \%$ \\
\hline LPCK & $-2,40 \%$ & $17,89 \%$ & 2,24 & $-1,15 \%$ \\
\hline OMRE & $2,38 \%$ & $23,94 \%$ & 2,76 & $0,80 \%$ \\
\hline PPRO & $1,52 \%$ & $17,16 \%$ & 1,52 & $0,88 \%$ \\
\hline & & & & \\
\hline
\end{tabular}




\begin{tabular}{lcccc}
\hline PTPP & $-1,41 \%$ & $14,99 \%$ & 2,50 & $-0,64 \%$ \\
\hline PWON & $0,24 \%$ & $10,16 \%$ & 1,42 & $0,04 \%$ \\
\hline SMRA & $-0,81 \%$ & $14,09 \%$ & 2,10 & $-0,47 \%$ \\
\hline WIKA & $-0,16 \%$ & $14,37 \%$ & 2,23 & $-0,15 \%$ \\
\hline CASS & $-2,36 \%$ & $11,10 \%$ & $-0,35$ & $7,16 \%$ \\
\hline ISAT & $-0,35 \%$ & $16,45 \%$ & 2,00 & $-0,26 \%$ \\
\hline MBSS & $1,46 \%$ & $16,36 \%$ & 1,26 & $1,02 \%$ \\
\hline PGAS & $-0,53 \%$ & $15,16 \%$ & 2,21 & $-0,32 \%$ \\
\hline RAJA & $0,82 \%$ & $21,38 \%$ & 1,73 & $0,37 \%$ \\
\hline SMDR & $0,58 \%$ & $16,41 \%$ & 1,51 & $0,27 \%$ \\
\hline AKRA & $-1,41 \%$ & $9,90 \%$ & 1,68 & $-0,95 \%$ \\
\hline EPMT & $-0,50 \%$ & $8,91 \%$ & $-0,36$ & $1,90 \%$ \\
\hline ERAA & $3,54 \%$ & $20,80 \%$ & 1,85 & $1,81 \%$ \\
\hline FAST & $2,24 \%$ & $17,62 \%$ & $-0,35$ & $-5,95 \%$ \\
\hline FISH & $2,97 \%$ & $21,21 \%$ & 0,99 & $2,81 \%$ \\
\hline LPPF & $-3,05 \%$ & $14,64 \%$ & 1,99 & $-1,62 \%$ \\
\hline MLPL & $-1,54 \%$ & $17,18 \%$ & 2,47 & $-0,70 \%$ \\
\hline PDES & $6,25 \%$ & $45,58 \%$ & 0,99 & $6,15 \%$ \\
\hline PTSP & $-1,48 \%$ & $5,51 \%$ & $-0,05$ & $32,73 \%$ \\
\hline SONA & $3,45 \%$ & $28,50 \%$ & $-0,43$ & $-7,61 \%$ \\
\hline SRAJ & $-0,87 \%$ & $14,23 \%$ & $-0,20$ & $5,20 \%$ \\
\hline TURI & $1,95 \%$ & $9,52 \%$ & $-0,13$ & $-13,66 \%$ \\
\hline WICO & $7,21 \%$ & $28,02 \%$ & $-0,21$ & $-33,56 \%$ \\
\hline Pasar & $0,08 \%$ & $3,85 \%$ & 1,00 & $-0,10 \%$ \\
\hline Rf & $0,18 \%$ & & & \\
\hline SR & & & \\
\hline
\end{tabular}

Sumber: Hasil data diolah

\section{Keputusan Investasi Dengan Metode CAPM}

Berdasarkan pada hasil perhitungan terdapat 65 saham yang undervalued, yang menunjukkan expected returnya $E(R i)$ lebih rendah dari average returnnya (Ri) dan excess return $E(R)$ adalah positif. Sehinga berdasarkan perhitungan dengan metode CAPM keputusan yang diambil oleh investor adalah membeli saham. Sedangkan terdapat 71 saham yang merupakan overvalued, menunjukkan expected returnnya $(E(R i))$ lebih tinggi dari average returnnya (Ri) dan hasil excess return $E(R)$ adalah negatif. Sehingga berdasarkan perhitungan dengan CAPM keputusan yang diambil oleh investor adalah menjual saham. Dibandingkan dengan penelitian sebelumnya yang dilakukan oleh Putri (2016) pada perusahaan sektor infrastruktur, utilitas dan transportasi di Bursa Efek Indonesia sebanyak 20 saham yang dijadikan sampel penelitian diperoleh 15 saham perusahaan yang termasuk undervalued (membeli saham), dan 5 saham perusahaan yang termasuk overvalued (menjual saham). Penelitian ini sejalan dengan penelitian Kennedy (2019) yang menghasilkan saham overvalued lebih banyak dibandingkan saham undervalued. Hal ini dapat memberikan investor pilihan untuk menentukan keputusan berinvestasi: membeli saham atau menjual sahamnya. saham dikategorikan undervalued berarti tingkat keuntungan lebih tinggi dari tingkat keuntungan yang diharapkan, dan tingkat keuntungan individu lebih rendah dari tingkat keuntungan yang diharapkan disebut overvalued. Pilihan ini agar investor tidak melakukan kesalahan dalam menentukan keputuan investasi saham. 
Tabel 4

Pengelompokan Keputusan Investasi Berdasarkan Capital Asset Pricing Model (CAPM)

\begin{tabular}{|c|c|c|c|c|c|c|c|c|c|}
\hline No & $\begin{array}{l}\text { Nama } \\
\text { Sektor }\end{array}$ & Saham & $\mathrm{Bi}$ & RBR & $\mathrm{Rm}$ & $\begin{array}{c}\text { Return } \\
\text { Saham } \\
\text { (Ri) }\end{array}$ & $E(R i)$ & Keterangan & Keputusan \\
\hline 1 & \multirow{4}{*}{ Pertanian } & AALI & 1,786 & 0,083 & 0,001 & $-0,004$ & $-0,064$ & Undervalued & Beli saham \\
\hline 2 & & $\mathrm{BISI}$ & 1,170 & 0,083 & 0,001 & $-0,003$ & $-0,013$ & Undervalued & Beli saham \\
\hline 3 & & ANJT & 0,491 & 0,083 & 0,001 & $-0,019$ & 0,043 & Overvalued & Jual saham \\
\hline 4 & & LSIP & 0,985 & 0,083 & 0,001 & $-0,002$ & 0,002 & Overvalued & Jual saham \\
\hline 5 & \multirow{12}{*}{$\begin{array}{l}\text { Pertam } \\
\text { bangan }\end{array}$} & ADRO & 1,611 & 0,083 & 0,001 & 0,019 & $-0,050$ & Undervalued & Beli saham \\
\hline 6 & & ANTM & 2,052 & 0,083 & 0,001 & 0,024 & $-0,086$ & Undervalued & Beli saham \\
\hline 7 & & BSSR & 0,005 & 0,083 & 0,001 & 0,013 & 0,083 & Overvalued & Jual saham \\
\hline 8 & & DSSA & $-0,422$ & 0,083 & 0,001 & 0,016 & 0,118 & Overvalued & Jual saham \\
\hline 9 & & GEMS & 0,059 & 0,083 & 0,001 & 0,015 & 0,078 & Overvalued & Jual saham \\
\hline 10 & & HRUM & 1,206 & 0,083 & 0,001 & 0,026 & $-0,016$ & Undervalued & Beli saham \\
\hline 11 & & INCO & 1,769 & 0,083 & 0,001 & 0,020 & $-0,063$ & Undervalued & Beli saham \\
\hline 12 & & ITMG & 1,777 & 0,083 & 0,001 & 0,016 & $-0,063$ & Undervalued & Beli saham \\
\hline 13 & & MBAP & 0,707 & 0,083 & 0,001 & 0,013 & 0,025 & Overvalued & Jual saham \\
\hline 14 & & $\mathrm{MYOH}$ & 0,357 & 0,083 & 0,001 & 0,017 & 0,054 & Overvalued & Jual saham \\
\hline 15 & & PTBA & $-1,003$ & 0,083 & 0,001 & 0,078 & 0,166 & Overvalued & Jual saham \\
\hline 16 & & TOBA & 0,595 & 0,083 & 0,001 & 0,064 & 0,034 & Undervalued & Beli saham \\
\hline 17 & \multirow{20}{*}{$\begin{array}{c}\text { Industri } \\
\text { Dasar } \\
\text { Dan Kimia }\end{array}$} & ADMG & 1,402 & 0,083 & 0,001 & 0,014 & $-0,032$ & Undervalued & Beli saham \\
\hline 18 & & ARNA & 0,859 & 0,083 & 0,001 & $-0,002$ & 0,012 & Overvalued & Jual saham \\
\hline 19 & & BRPT & 2,467 & 0,083 & 0,001 & 0,093 & $-0,120$ & Undervalued & Beli saham \\
\hline 20 & & CPIN & 1,054 & 0,083 & 0,001 & 0,019 & $-0,004$ & Undervalued & Beli saham \\
\hline 21 & & CTBN & 0,337 & 0,083 & 0,001 & $-0,012$ & 0,055 & Overvalued & Jual saham \\
\hline 22 & & EKAD & 0,883 & 0,083 & 0,001 & 0,020 & 0,010 & Undervalued & Beli saham \\
\hline 23 & & FPNI & 2,094 & 0,083 & 0,001 & 0,041 & $-0,090$ & Undervalued & Beli saham \\
\hline 24 & & GDST & 0,205 & 0,083 & 0,001 & 0,016 & 0,066 & Overvalued & Jual saham \\
\hline 25 & & IMPC & 0,139 & 0,083 & 0,001 & 0,006 & 0,072 & Overvalued & Jual saham \\
\hline 26 & & INTP & 1,276 & 0,083 & 0,001 & $-0,007$ & $-0,022$ & Undervalued & Beli saham \\
\hline 27 & & IPOL & 1,273 & 0,083 & 0,001 & 0,005 & $-0,022$ & Undervalued & Beli saham \\
\hline 28 & & KDSI & 1,241 & 0,083 & 0,001 & 0,035 & $-0,019$ & Undervalued & Beli saham \\
\hline 29 & & KIAS & 0,091 & 0,083 & 0,001 & $-0,009$ & 0,076 & Overvalued & Jual saham \\
\hline 30 & & $\mathrm{PICO}$ & 1,790 & 0,083 & 0,001 & 0,077 & $-0,064$ & Undervalued & Beli saham \\
\hline 31 & & SMBR & 3,005 & 0,083 & 0,001 & 0,031 & $-0,165$ & Undervalued & Beli saham \\
\hline 32 & & TOTO & 0,727 & 0,083 & 0,001 & $-0,019$ & 0,023 & Overvalued & Jual saham \\
\hline 33 & & TPIA & 1,962 & 0,083 & 0,001 & 0,058 & $-0,079$ & Undervalued & Beli saham \\
\hline 34 & & TRST & $-0,132$ & 0,083 & 0,001 & 0,006 & 0,094 & Overvalued & Jual saham \\
\hline 35 & & UNIC & 0,383 & 0,083 & 0,001 & 0,030 & 0,052 & Overvalued & Jual saham \\
\hline 36 & & WTON & 1,441 & 0,083 & 0,001 & $-0,013$ & $-0,036$ & Undervalued & Beli saham \\
\hline 37 & \multirow{3}{*}{ Industri } & ASII & 1,503 & 0,083 & 0,001 & $-0,001$ & $-0,041$ & Undervalued & Beli saham \\
\hline 38 & & AUTO & 1,103 & 0,083 & 0,001 & $-0,007$ & $-0,008$ & Undervalued & Beli saham \\
\hline 39 & & BOLT & 0,081 & 0,083 & 0,001 & 0,000 & 0,077 & Overvalued & Jual saham \\
\hline
\end{tabular}




\begin{tabular}{|c|c|c|c|c|c|c|c|c|c|}
\hline 40 & & BRAM & 0,727 & 0,083 & 0,001 & 0,033 & 0,023 & Undervalued & Beli saham \\
\hline 41 & & INDR & 0,065 & 0,083 & 0,001 & 0,045 & 0,078 & Overvalued & Jual saham \\
\hline 42 & & INDS & 1,275 & 0,083 & 0,001 & 0,014 & $-0,022$ & Undervalued & Beli saham \\
\hline 43 & & KBLI & 1,149 & 0,083 & 0,001 & 0,035 & $-0,012$ & Undervalued & Beli saham \\
\hline 44 & & MASA & $-0,815$ & 0,083 & 0,001 & 0,025 & 0,151 & Overvalued & Jual saham \\
\hline 45 & & SCCO & 0,496 & 0,083 & 0,001 & 0,020 & 0,042 & Overvalued & Jual saham \\
\hline 46 & & SMSM & 0,545 & 0,083 & 0,001 & 0,001 & 0,038 & Overvalued & Jual saham \\
\hline 47 & & TFCO & 2,338 & 0,083 & 0,001 & 0,006 & $-0,110$ & Undervalued & Beli saham \\
\hline 48 & & VOKS & 4,203 & 0,083 & 0,001 & 0,118 & $-0,264$ & Undervalued & Beli saham \\
\hline 49 & \multirow{16}{*}{$\begin{array}{c}\text { Barang } \\
\text { Konsumsi }\end{array}$} & DVLA & 0,101 & 0,083 & 0,001 & 0,011 & 0,075 & Overvalued & Jual saham \\
\hline 50 & & ICBP & 0,443 & 0,083 & 0,001 & 0,008 & 0,047 & Overvalued & Jual saham \\
\hline 51 & & IIKP & 0,460 & 0,083 & 0,001 & $-0,025$ & 0,045 & Overvalued & Jual saham \\
\hline 52 & & INAF & $-0,463$ & 0,083 & 0,001 & 0,096 & 0,121 & Overvalued & Jual saham \\
\hline 53 & & INDF & 0,792 & 0,083 & 0,001 & 0,007 & 0,018 & Overvalued & Jual saham \\
\hline 54 & & KAEF & $-0,852$ & 0,083 & 0,001 & 0,034 & 0,154 & Overvalued & Jual saham \\
\hline 55 & & KLBF & 1,084 & 0,083 & 0,001 & 0,004 & $-0,006$ & Undervalued & Beli saham \\
\hline 56 & & MERK & 0,968 & 0,083 & 0,001 & $-0,012$ & 0,003 & Overvalued & Jual saham \\
\hline 57 & & MYOR & 0,178 & 0,083 & 0,001 & 0,014 & 0,069 & Overvalued & Jual saham \\
\hline 58 & & ROTI & 0,500 & 0,083 & 0,001 & 0,001 & 0,042 & Overvalued & Jual saham \\
\hline 59 & & SIDO & 1,075 & 0,083 & 0,001 & 0,035 & $-0,005$ & Undervalued & Beli saham \\
\hline 60 & & SKLT & 0,270 & 0,083 & 0,001 & 0,036 & 0,061 & Overvalued & Jual saham \\
\hline 61 & & TCID & 0,051 & 0,083 & 0,001 & $-0,013$ & 0,079 & Overvalued & Jual saham \\
\hline 62 & & TSPC & 0,874 & 0,083 & 0,001 & $-0,001$ & 0,011 & Overvalued & Jual saham \\
\hline 63 & & ULTJ & $-0,129$ & 0,083 & 0,001 & 0,019 & 0,094 & Overvalued & Jual saham \\
\hline 64 & & UNVR & 0,706 & 0,083 & 0,001 & 0,003 & 0,025 & Overvalued & Jual saham \\
\hline 65 & \multirow{19}{*}{ Properti } & $\mathrm{ADHI}$ & 1,814 & 0,083 & 0,001 & $-0,016$ & $-0,066$ & Undervalued & Beli saham \\
\hline 66 & & APLN & 1,666 & 0,083 & 0,001 & $-0,011$ & $-0,054$ & Undervalued & Beli saham \\
\hline 67 & & ASRI & 1,775 & 0,083 & 0,001 & $-0,012$ & $-0,063$ & Undervalued & Beli saham \\
\hline 68 & & BEST & 2,132 & 0,083 & 0,001 & $-0,008$ & $-0,093$ & Undervalued & Beli saham \\
\hline 69 & & BKSL & 1,128 & 0,083 & 0,001 & 0,009 & $-0,010$ & Undervalued & Beli saham \\
\hline 70 & & BSDE & 1,408 & 0,083 & 0,001 & $-0,012$ & $-0,033$ & Undervalued & Beli saham \\
\hline 71 & & CTRA & 1,668 & 0,083 & 0,001 & $-0,007$ & $-0,054$ & Undervalued & Beli saham \\
\hline 72 & & DILD & 0,265 & 0,083 & 0,001 & $-0,014$ & 0,061 & Overvalued & Jual saham \\
\hline 73 & & DMAS & 1,649 & 0,083 & 0,001 & 0,003 & $-0,053$ & Undervalued & Beli saham \\
\hline 74 & & DUTI & 0,521 & 0,083 & 0,001 & 0,013 & 0,040 & Overvalued & Jual saham \\
\hline 75 & & GMTD & $-0,350$ & 0,083 & 0,001 & 0,018 & 0,112 & Overvalued & Jual saham \\
\hline 76 & & INPP & 0,562 & 0,083 & 0,001 & 0,016 & 0,037 & Overvalued & Jual saham \\
\hline 77 & & JKON & 0,106 & 0,083 & 0,001 & $-0,011$ & 0,075 & Overvalued & Jual saham \\
\hline 78 & & JRPT & 1,052 & 0,083 & 0,001 & $-0,006$ & $-0,004$ & Overvalued & Jual saham \\
\hline 79 & & KIJA & 1,627 & 0,083 & 0,001 & $-0,003$ & $-0,051$ & Undervalued & Beli saham \\
\hline 80 & & LPCK & 2,239 & 0,083 & 0,001 & $-0,024$ & $-0,102$ & Undervalued & Beli saham \\
\hline 81 & & LPKR & 1,544 & 0,083 & 0,001 & $-0,022$ & $-0,044$ & Undervalued & Beli saham \\
\hline 82 & & MKPI & 0,280 & 0,083 & 0,001 & 0,003 & 0,060 & Overvalued & Jual saham \\
\hline 83 & & MTLA & 1,024 & 0,083 & 0,001 & 0,016 & $-0,001$ & Undervalued & Beli saham \\
\hline
\end{tabular}




\begin{tabular}{|c|c|c|c|c|c|c|c|c|c|}
\hline 84 & & OMRE & 2,758 & 0,083 & 0,001 & 0,024 & $-0,144$ & Undervalued & Beli saham \\
\hline 85 & & PPRO & 1,520 & 0,083 & 0,001 & 0,015 & $-0,042$ & Undervalued & Beli saham \\
\hline 86 & & PTPP & 2,496 & 0,083 & 0,001 & $-0,014$ & $-0,123$ & Undervalued & Beli saham \\
\hline 87 & & PWON & 1,422 & 0,083 & 0,001 & 0,002 & $-0,034$ & Undervalued & Beli saham \\
\hline 88 & & SMRA & 2,104 & 0,083 & 0,001 & $-0,008$ & $-0,090$ & Undervalued & Beli saham \\
\hline 89 & & SSIA & 0,955 & 0,083 & 0,001 & $-0,002$ & 0,004 & Overvalued & Jual saham \\
\hline 90 & & WIKA & 2,226 & 0,083 & 0,001 & $-0,002$ & $-0,100$ & Undervalued & Beli saham \\
\hline 91 & \multirow{12}{*}{$\begin{array}{c}\text { Infra } \\
\text { struktur }\end{array}$} & BIRD & 1,325 & 0,083 & 0,001 & $-0,024$ & $-0,026$ & Undervalued & Beli saham \\
\hline 92 & & CASS & $-0,354$ & 0,083 & 0,001 & $-0,024$ & 0,113 & Overvalued & Jual saham \\
\hline 93 & & CMNP & 0,146 & 0,083 & 0,001 & $-0,002$ & 0,071 & Overvalued & Jual saham \\
\hline 94 & & IATA & 0,003 & 0,083 & 0,001 & 0,000 & 0,083 & Overvalued & Jual saham \\
\hline 95 & & ISAT & 1,995 & 0,083 & 0,001 & $-0,003$ & $-0,081$ & Undervalued & Beli saham \\
\hline 96 & & MBSS & 1,259 & 0,083 & 0,001 & 0,015 & $-0,021$ & Undervalued & Beli saham \\
\hline 97 & & META & 1,082 & 0,083 & 0,001 & 0,012 & $-0,006$ & Undervalued & Beli saham \\
\hline 98 & & PGAS & 2,205 & 0,083 & 0,001 & $-0,005$ & $-0,099$ & Undervalued & Beli saham \\
\hline 99 & & RAJA & 1,731 & 0,083 & 0,001 & 0,008 & $-0,060$ & Undervalued & Beli saham \\
\hline 100 & & SMDR & 1,507 & 0,083 & 0,001 & 0,006 & $-0,041$ & Undervalued & Beli saham \\
\hline 101 & & TLKM & 0,587 & 0,083 & 0,001 & 0,001 & 0,035 & Overvalued & Jual saham \\
\hline 102 & & WINS & 0,482 & 0,083 & 0,001 & $-0,002$ & 0,043 & Overvalued & Jual saham \\
\hline 103 & $\begin{array}{c}\text { Keuang } \\
\text { an }\end{array}$ & PNBS & 0,339 & 0,083 & 0,001 & $-0,024$ & 0,055 & Overvalued & Jual saham \\
\hline 104 & \multirow{23}{*}{$\begin{array}{l}\text { Perdagan } \\
\text { gan }\end{array}$} & ACES & 0,726 & 0,083 & 0,001 & 0,014 & 0,023 & Overvalued & Jual saham \\
\hline 105 & & AKRA & 1,683 & 0,083 & 0,001 & $-0,014$ & $-0,056$ & Undervalued & Beli saham \\
\hline 106 & & ASGR & 0,278 & 0,083 & 0,001 & $-0,016$ & 0,060 & Overvalued & Jual saham \\
\hline 107 & & BMTR & 1,569 & 0,083 & 0,001 & $-0,021$ & $-0,046$ & Undervalued & Beli saham \\
\hline 108 & & CSAP & 0,205 & 0,083 & 0,001 & 0,000 & 0,066 & Overvalued & Jual saham \\
\hline 109 & & ECII & 0,448 & 0,083 & 0,001 & 0,003 & 0,046 & Overvalued & Jual saham \\
\hline 110 & & EPMT & $-0,355$ & 0,083 & 0,001 & $-0,005$ & 0,113 & Overvalued & Jual saham \\
\hline 111 & & ERAA & 1,853 & 0,083 & 0,001 & 0,035 & $-0,070$ & Undervalued & Beli saham \\
\hline 112 & & FAST & $-0,347$ & 0,083 & 0,001 & 0,022 & 0,112 & Overvalued & Jual saham \\
\hline 113 & & $\mathrm{FISH}$ & 0,994 & 0,083 & 0,001 & 0,030 & 0,001 & Undervalued & Beli saham \\
\hline 114 & & HERO & 0,129 & 0,083 & 0,001 & $-0,003$ & 0,073 & Overvalued & Jual saham \\
\hline 115 & & JIHD & 0,090 & 0,083 & 0,001 & 0,000 & 0,076 & Overvalued & Jual saham \\
\hline 116 & & JSPT & 0,452 & 0,083 & 0,001 & 0,013 & 0,046 & Overvalued & Jual saham \\
\hline 117 & & JTPE & 0,667 & 0,083 & 0,001 & 0,029 & 0,028 & Undervalued & Beli saham \\
\hline 118 & & KPIG & 0,562 & 0,083 & 0,001 & $-0,001$ & 0,037 & Overvalued & Jual saham \\
\hline 119 & & LPPF & 1,989 & 0,083 & 0,001 & $-0,031$ & $-0,081$ & Undervalued & Beli saham \\
\hline 120 & & LTLS & 0,839 & 0,083 & 0,001 & 0,002 & 0,014 & Overvalued & Jual saham \\
\hline 121 & & MIKA & 0,940 & 0,083 & 0,001 & 0,004 & 0,006 & Overvalued & Jual saham \\
\hline 122 & & MLPL & 2,466 & 0,083 & 0,001 & $-0,015$ & $-0,120$ & Undervalued & Beli saham \\
\hline 123 & & MLPT & 0,263 & 0,083 & 0,001 & 0,007 & 0,062 & Overvalued & Jual saham \\
\hline 124 & & MPPA & 1,497 & 0,083 & 0,001 & $-0,033$ & $-0,040$ & Undervalued & Beli saham \\
\hline 125 & & MTDL & 0,888 & 0,083 & 0,001 & 0,017 & 0,010 & Undervalued & Beli saham \\
\hline 126 & & PDES & 0,988 & 0,083 & 0,001 & 0,063 & 0,002 & Undervalued & Beli saham \\
\hline
\end{tabular}




\begin{tabular}{|c|c|c|c|c|c|c|c|c|}
\hline 127 & PJAA & 1,296 & 0,083 & 0,001 & $-0,020$ & $-0,024$ & Undervalued & Beli saham \\
\hline 128 & PTSP & $-0,051$ & 0,083 & 0,001 & $-0,015$ & 0,087 & Overvalued & Jual saham \\
\hline 129 & SHID & 0,166 & 0,083 & 0,001 & 0,045 & 0,070 & Overvalued & Jual saham \\
\hline 130 & SILO & 0,376 & 0,083 & 0,001 & $-0,002$ & 0,052 & Overvalued & Jual saham \\
\hline 131 & SONA & $-0,430$ & 0,083 & 0,001 & 0,034 & 0,119 & Overvalued & Jual saham \\
\hline 132 & SRAJ & $-0,201$ & 0,083 & 0,001 & $-0,009$ & 0,100 & Overvalued & Jual saham \\
\hline 133 & TGKA & 0,564 & 0,083 & 0,001 & 0,028 & 0,037 & Overvalued & Jual saham \\
\hline 134 & TURI & $-0,129$ & 0,083 & 0,001 & 0,019 & 0,094 & Overvalued & Jual saham \\
\hline 135 & UNTR & 0,559 & 0,083 & 0,001 & 0,003 & 0,037 & Overvalued & Jual saham \\
\hline 136 & WICO & $-0,210$ & 0,083 & 0,001 & 0,072 & 0,101 & Overvalued & Jual saham \\
\hline
\end{tabular}

Sumber: Hasil Data Diolah

\section{PENUTUP \\ Kesimpulan}

Berdasarkan analisis dan pembahasan dengan perhitungan menggunakan metode model indeks tunggal, treynor index dan Capital Asset Pricing Model (CAPM) pada saham-saham yang masuk Indeks Saham Syariah Indonesia (ISSI) di Bursa Efek Indonesia periode tahun 2016-2020, maka dapat ditarik kesimpulan sebagai berikut:

Terdapat 54 saham yang memenuhi kriteria pembentukan portofolio optimal saham yaitu terdapat di sektor pertanian berjumlah 1 saham (BISI), sektor tambang yaitu 4 saham (ANTM, DSSA, PTBA, TOBA), sektor industri dasar dan kimia berjumlah 7 saham (BRPT, FPNI, KDSI, PICO, SMBR, TPIA, TRST), sektor industri berjumlah 4 saham (KBLI, MASA, TFCO, VOKS), sektor konsumsi berjumlah 4 saham (INAF, KAEF, SIDO, ULTJ), sektor saham properti, real estate dan kontruksi bangunan berjumlah 15 saham (ADHI, APLN, ASRI, BEST, CTRA, DMAS, GMTD, KIJA, LPCK, OMRE, PPRO, PTPP, PWON, SMRA, WIKA), sektor saham infrastruktur, utilitas, dan transportasi yaitu 6 saham (CASS, ISAT, MBSS, PGAS, RAJA, SMDR), dan saham perdagangan, jasa dan investasi yaitu 13 saham (AKRA, EPMT, ERAA, FAST, FISH, LPPF, MLPL, PDES, PTSP, SONA, SRAJ, TURI, WICO).

Besarnya proporsi dana yang layak diinvestasikan pada 54 saham tersebut adalah saham sektor pertanian adalah saham BISI sebesar 3,41\%, sektor tambang yaitu saham ANTM sebesar $0,53 \%$, DSSA sebesar $1,92 \%$, PTBA sebesar $0,03 \%$, TOBA sebesar $0,02 \%$, sektor industri dasar dan kimia yaitu saham BRPT sebesar - $0,45 \%$, FPNI sebesar 0,01\%, KDSI sebesar 0,67\%, PICO sebesar $-0,04 \%$, SMBR sebesar $-0,002 \%$, TPIA sebesar $-0,13 \%$, TRST sebesar $8,17 \%$, sektor industri yaitu saham KBLI sebesar 0,39\%, MASA sebesar 0,85\%, TFCO sebesar 0,39\%, VOKS sebesar $-0,09 \%$, sektor konsumsi yaitu saham INAF sebesar $-0,01 \%$, KAEF sebesar $0,32 \%$, SIDO sebesar $0,65 \%$, ULTJ sebesar 3,18\%, sektor saham properti, real estate dan kontruksi bangunan yaitu saham ADHI sebesar 2,87\%, APLN sebesar 1,90\%, ASRI sebesar 4,24\%, BEST sebesar 1,77\%, CTRA sebesar 2,56\%, DMAS sebesar 2,48\%, GMTD sebesar 5,38\%, KIJA sebesar 4,49\%, LPCK sebesar 1,21\%, OMRE sebesar 0,11\%, PPRO sebesar 0,70\%, PTPP sebesar 1,77\%, PWON sebesar 3,34\%, SMRA sebesar 1,79\%, WIKA sebesar 1,51\%, sektor saham infrastruktur, utilitas, dan transportasi yaitu saham CASS sebesar 4,05\%, ISAT sebesar $1,07 \%$, MBSS sebesar $0,83 \%$, PGAS sebesar $1,38 \%$, RAJA sebesar $0,47 \%$, SMDR sebesar $0,95 \%$, dan saham perdagangan, jasa dan investasi yaitu saham AKRA sebesar 5,30\%, EPMT sebesar $5,29 \%$, ERAA sebesar 0,18\%, FAST sebesar 0,94\%, FISH sebesar 0,36\%, LPPF sebesar 2,21\%, MLPL sebesar 1,18\%, PDES sebesar $0,01 \%$, PTSP sebesar $14,21 \%$, SONA sebesar 0,30\%, SRAJ sebesar $2,06 \%$, TURI sebesar 3,18\%, WICO sebesar $0,08 \%$. 
Portofolio optimal dari saham-saham Indeks Saham Syariah Indonesia (ISSI) tersebut memiliki tingkat return portofolio sebesar 0,21946 (21,95\%) dan risiko portofolio sebesar 0,1049 (10,49\%), dimana nilai return portofolio menunjukkan tingkat pengembalian (keuntungan) dalam berinvestasi. Sedangkan nilai risiko portofolio menunjukkan kerugian yang harus dihadapi dalam berinvestasi. Risiko yang diperoleh dari pembentukan portofolio ini lebih kecil dibandingkan jika berinvestasi dengan saham individual.

Evaluasi kinerja portofolio berdasarkan metode treynor index menunjukkan bahwa saham yang terbaik dari ke 54 saham yaitu saham PTSP sebesar $32,73 \%$ dan nilai saham yang terendah yaitu saham TURI sebesar $-13,66 \%$.

Berdasarkan perhitungan Capital Asset Pricing Model dari 136 saham terdapat 65 saham yang undervalued, yang menunjukkan tingkat return individu yang lebih besar di banding tingkat return yang diharapkan $\left(R_{i}>E\left(R_{i}\right)\right)$ sehingga keputusan yang diambil oleh investor adalah membeli saham. Sedangkan 71 saham yang merupakan overvalued, menunjukkan tingkat return individu yang lebih kecil dibanding return yang diharapkan $\left(R_{i}<E\left(R_{i}\right)\right)$ sehingga keputusan yang diambil oleh investor adalah menjual saham. Hal ini dapat memberikan investor pilihan untuk menentukan keputusan berinvestasi: membeli saham atau menjual sahamnya. saham dikategorikan undervalued berarti tingkat keuntungan lebih tinggi dari tingkat keuntungan yang diharapkan, dan tingkat keuntungan individu lebih rendah dari tingkat keuntungan yang diharapkan disebut overvalued. Pilihan ini agar investor tidak melakukan kesalahan dalam menentukan keputuan investasi saham.

\section{Saran}

Berdasarkan hasil analisis dan pembahasan pada pembentukan portofolio optimal pada sahamsaham yang terdaftar di Indeks Saham Syariah Indonesia (ISSI) di Bursa Efek Indonesia pada periode tahun 2016 sampai Juni 2020, maka peneliti menyampaikan saran-saran yang dapat diberikan sebagai berikut:

1. Penelitian selanjutnya disarankan untuk melakukan penelitian menggunakan periode terbaru untuk mendapatkan hasil penelitian yang lebih akurat.

2. Bagi perusahaan yang sahamnya belum termasuk kategori portofolio optimal, dapat melakukan perbaikan kinerja perusahaan agar sahamnya meningkat.

3. Bagi investor dapat menginvestasikan dananya pada 54 saham tersebut sebagai alternatif pilihan untuk berinvestasi saham syariah di pasar modal syariah.

4. Bagi akademisi, penelitian ini dapat dijadikan salah satu referensi ilmiah dalam pengembangan ilmu Ekonomi Syariah tentang analisis portofolio optimal menggunakan model indeks tunggal dan pengambilan keputusan dalam berinvestasi dengan Capital Asset Pricing Model (CAPM).

\section{DAFTAR PUSTAKA:}

Darmawan, I. P. P., dan Purnawati, N. K. (2015). Pembentukan Portofolio Optimal Pada Saham-Saham Di Indeks LQ 45 Dengan Menggunakan Model Indeks Tunggal. E-Jurnal Manajemen Universitas Udayana, 4(12), 43354361.

Fahmi, I. (2018). Pengantar Teori Portofolio dan Analisis Investasi. Alfabet.

Hadi, N. (2015). Pasar Modal: Edisi 2. Graha IImu.

Halim, A. (2005). Analisis Investasi. Salemba Empat.

Hartono, J. (2017). Teori Portofolio dan Analisis Investasi: Edisi Kesebelas. BPFE Yogyakarta.

Hati, S. W., dan Harefa, W. S. (2019). Analisis Faktor-Faktor Yang Mempengaruhi Minat Berinvestasi Di Pasar Modal Bagi Generasi Milenial (Studi Pada Mahasiswi Jurusan Manajemen Bisnis Politeknik Negeri Batam). Journal of Business Administration, 3(2), 281-295.

Husnan, S. (2003). Dasar-dasar Teori Portofolio dan Analisis Sekuritas. UPP AMP YKPN. 
Kennedy, P. S. J., dan Yanis, A. (2019). Penentuan Keputusan Investasi Saham Berdasarkan Undervalued Atau Overvalued Price. Jurnal Akuntansi Dan Ekonomi FE. UN PGRI Kediri, 4(3), 1-9.

Lestari, F., dan Yunita, I. (2019). Analisis Investasi Portofolio Saham Optimal pada Sektor Perbankan Menggunakan Metode Model Indeks Tunggal dan Capital Asset Pricing Model (CAPM) (Studi pada Perusahaan Sub Sektor Bank yang Tercatat di Indeks LQ 45 Bursa Efek Indonesia Tahun 2012-2016). EProceeding of Management, 6(1), 115-121.

OJK. (2012). Kriteria dan Penerbitan Daftar Efek Syariah. www.ojk.go.id.

Putra, M. D. M., dan Yadnya, P. (2016). Penerapan Metode Capital Asset Pricing Model Sebagai Pertimbangan Dalam Pengambilan Keputusan Investasi Saham. E-Jurnal Manajemen Unud, 5(12), 8079-8106.

Suroto. (2015). Analisis Portofolio Optimal Menurut Model Indeks Tunggal (Studi Empiris Pada Saham LQ 45 Di Bursa Efek Indonesia Periode Agustus 2012-Juli 2015). Media Ekonomi Dan Manajemen, 30(2), 161-177.

Suryani, dan Hendryadi. (2016). Metodologi Riset Kuantitatif: Teori dan Aplikasi Pada Penelitian Bidang Manajemen dan Ekonomi Islam. Prenadamedia Group.

Syulviya, S. A. (2015). Evaluasi Kinerja Investasi Portofolio Dengan Menggunakan Model Treynor (Studi Pada Perusahaan Food dan Beverages Yang Listing Di BEI Periode 2013). Jurnal Administrasi Bisnis S1 Universitas Brawijaya, 23(1), 1-10.

Tandelilin, E. (2001). Analisis Investasi dan Manajemen Portofolio (Edisi Pertama). BPFE Yogyakarta.

Tandelilin, E. (2010). Portofolio Dan Analisis Investasi: Teori dan Aplikasi Edisi Pertama. Kanisius.

Umam, K., dan Sutanto, H. (2017). Manajemen Ivestasi. Pustaka Setia.

Zubir, Z. (2013). Manajemen Portofolio: Penerapan Dalam Investasi Saham. Salemba Empat. 